
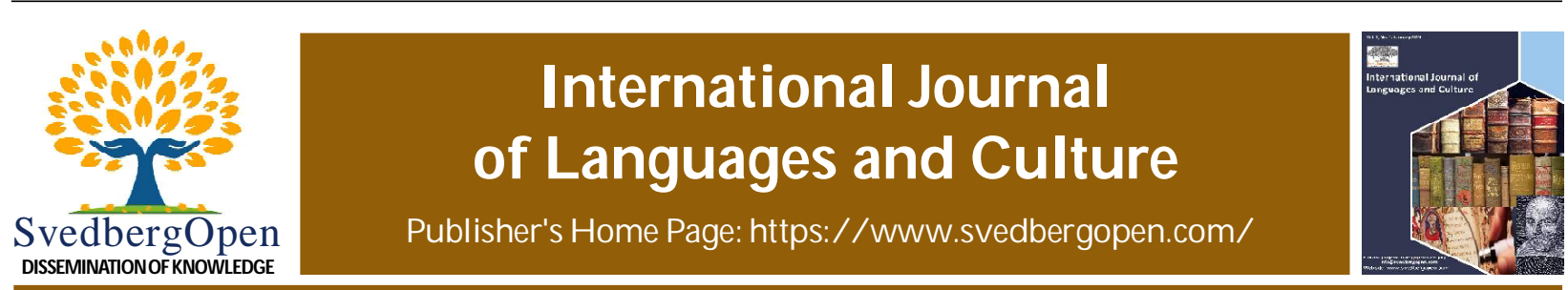

Research Paper

O pen A ccess

\title{
Components of advice giving and responses in Egyptian Arabic and American English
}

\author{
Hala Rashed Hosni ${ }^{*}$ \\ ${ }^{1}$ Assistant professor at Taibah university (currently), Fayoum university, Egypt. E-mail: hrh00@fayoum.edu.eg
}

\begin{tabular}{|c|c|}
\hline $\begin{array}{l}\text { Article Info } \\
\text { Volume 1, Issue 1, March 2021 } \\
\text { Received : } 11 \text { November } 2020 \\
\text { Accepted : } 07 \text { February } 2021 \\
\text { Published : } 05 \text { March 2021 } \\
\text { doi: 10.51483/IJLC.1.1.2021.42-78 }\end{array}$ & 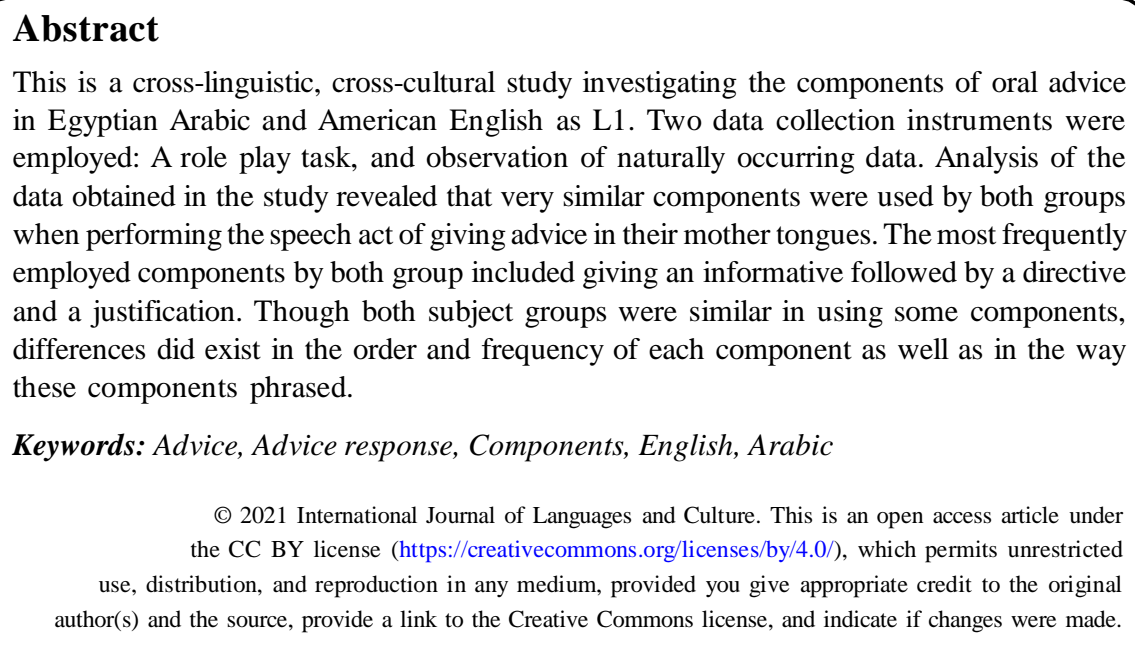 \\
\hline
\end{tabular}

\section{Introduction}

Advice giving means recommending a course of action that the speaker believes to be in the hearer's best interest. It might cover acts which have been referred to in the literature as 'suggestions' or 'recommendation' on condition that they advocate a course of action for the benefit of the addressee (Searle, 1969; Tsui, 1994). Despite the fact that most speech acts have been identified as problematic for learners of all levels, Fujimori and Houck (2004) revealed that the speech act of advice-giving in particular is often misused by none-native speakers (NNSs) because learners of English as a Foreign Language (EFL) usually experience two types of problems when giving advice: (a) use of advice in situations in which advice is considered inappropriate; and (b) use of inappropriate linguistic forms to express advice. Consequently, transferring first language (L1) pragmatic rules into second language (L2) when giving advice should be avoided because it may result in inappropriate speech acts.

Responding to a piece of advice is not an easy task either. Unfortunately speech act responses have been given very little attention in the literature. Tsui (1994) states that there are three major subclasses of responding acts: positive responding in which the addressee agrees with the addresser and is realized by compliance; negative responding in which the addressee refuses the act initiated by the addresser; and temporization in which the addressee postpones the decision making. Of these three types refusals constitute a major challenge to both the speaker and the hearer alike because they are highly face threatening acts and sometimes require a long sequence of negotiation. Consequently, in case of reluctance to accept the advice, direct refusals are not usually employed; instead, the hearer may resort to

\footnotetext{
* Corresponding author: Hala Rashed Hosni, Assistant Professor at Taibah University (currently), Affiliation: Fayoum University,
} Egypt. E-mail: IJLC121120200P6A 
hedged disagreement expressed in such forms as "Yes, but .." or "I wouldn't say that exactly" to avoid direct refusal and minimize the risk involved in performing an act which can be severely threatening to the advisor (Wardhaugh, 1985).

In order to avoid misunderstandings that may happen due to cultural differences, Boxer (1996) states that before we teach rules of speaking to language learners, we need to "tap into the tacit knowledge of native speakers of the language" to find out the true functions of different language forms. Crystal (1985) asserts the same point by defining pragmatics as "the study of language from the point of view of its users, especially the choices they make, the constraints they encounter in using language in social interaction and the effect their use of language has on other participants in the act of communication". Thus, conducting research into the speech behavior of NSs of different languages is important not only for establishing descriptions of how NSs perform different acts in their day-to-day interaction, but also for making use of this basic information for second language teaching.

Unfortunately, most speech act studies have been criticized for being ethnocentric, concentrating on English (Nelson et al., 1996). The present study, however, is different because it attempts to contribute to an understanding of the sociolinguistic rules of Egyptian Arabic as well as those of American English. Conducting research on Egyptian Arabic speech acts is very important not only due to the lack of research on Arabic pragmatics (Nydell, 1996) but also due to the great cultural differences that exist between the western societies and Middle Eastern ones (Brown, 2005) as well.

The literature associated with speech acts has also revealed that the perception of these acts differs according to the society (Coulmas, 1981; Ferguson, 1981; Davies, 1987; Wierzbicka, 1991). Consequently, the way they are performed differs as well. While advice giving, for example, is perceived as a sign of solidarity and establishing rapport in the Korean society (Park, 2002; Byon, 2006), it could be perceived as a sign of intrusion and interference in the individualistic American society (Ting-Toomey, 1999). Thus, it is apparent that the field of contrastive pragmatics needs more studies contrasting different speech acts within different speech communities.

It should be mentioned at this point that this study is a "descriptive" rather than a "prescriptive" one. It is meant to describe the speech act of advice giving as it is performed by the two subject groups under investigation. The study has both a linguistic and a cultural focus. Linguistically, it aims at exploring the appropriate linguistic forms used to give and to respond to advice in the two languages involved. Culturally, the intent of the study is to investigate how Americans as well as Egyptians perceive and perform the speech act of advice giving in their L1. It is perhaps a good idea to remark that the aim of this study is neither to make judgments about these cultures nor to compare them in terms of better or worse. Rather it is an attempt to establish and reinforce the cultural and social identity of each group. This type of knowledge does not only help us understand the social behavior of people from different cultural backgrounds but it helps to sensitize learners of different languages as to how different acts could be performed as well.

\section{Methodology}

In an attempt to reach reliable results, this study combines two data collection instruments: A role play task, and observation sheets to collect naturally occurring data.

\subsection{Role play task}

First, to collect semi-natural data, an oral role play task was used, consisting of 32 situations: 16 eliciting advice and 16 eliciting responses to advice (Appendices 1 and 2). Among the 16 situations, situations $(1,3,4,6,7)$ were adapted from Hinkel (1997), though some revisions were made to the original. Situations $(2,5,8,9,10,11,12,13,14,15$, and 16), on the other hand, were either originated by the researcher or adapted from authentic advice-giving instances encountered by the researcher or some of her friends.

\subsection{Observation of naturally occurring data}

Second, an observation sheet (Appendices 3A and 3B) was designed to collect naturally occurring data including pieces of advice and responses when available.

\subsection{Subjects}

The subjects participating in this study were 80 (40 Americans and 40 Egyptians) graduate and undergraduate students studying in the American University in Cairo (AUC) and Fayoum University. Forty Egyptians responded to the Arabic version of the role play task and forty Americans to the English one. All the selected subjects were between the age of 20 to 35 .

To analyze the act of advice giving in terms of components, the exchanges in the role play task and natural data were analyzed as consisting of a sequence of semantic formulas. For example, if a respondent gave advice saying: "Hello 
professor, you look really tired. You should go home and get some rest", this was coded as [greeting - assertive directive]. Responses to advice were coded in the same way. An example of a response for the previous advice was: "Thanks for your concern, but really everything is ok. I just have a presentation tomorrow." This was coded as: [thanking + refusal + justification].

After analyzing each utterance in terms of components, the researcher did a frequency count of each component in each instrument. Then these frequency counts were converted to percentages and assigned a relative rank in relation to other components employed by each group (Tables 1, 2, 3, and 4 for complete lists). However, it should be noted that these components are not fixed templates; they might differ according to the social and linguistic context.

At this point it should be mentioned that the present study did not use any particular model in analyzing the data obtained in terms of components. The analysis of the components of the speech act of advice giving and responses, however, draws upon some of the criteria used in Burton (1980), Hatch (1992), and Salah-El-Din (2000).

\section{Results}

This section presents a quantitative and qualitative analyses of the data collected for the study. It reports the components used by Egyptians and Americans in performing the speech act of advice giving and responses.

\subsection{Components of the speech act}

To specify the components of advice giving and responses in Egyptian Arabic and American English as L1 the situations of the role play task as well as the natural data were analyzed separately along the following lines:

Speech act type (components).

Frequency of each component within each situation.

Order of these components.

Frequency of each component in all situations.

The most difficult problem that faced the researcher when analyzing the data is the fact that there is no one-to-one correspondence between the illocutionary force and utterances. In other words, there are many ways in which the same utterance can be labeled. To solve this problem both sequential context and linguistic context were employed to assign utterance functions.

Analysis of the data collected revealed that before performing the act of advice giving, most subjects performed other acts to prepare the hearer for the coming advice. Consequently, the components of the speech act of advice giving were classified according to three different functions in the advice-giving sequence.

Pre-advice move(s): The action(s) performed before advice. It could be a statement and/or question used to inform the hearer of an instant wish to say something.

Head act: The part(s) that serves to perform the advice independently from other elements.

Post advice move(s): The part(s) that follows the head act and justifies or concludes the advice.

Following is the analysis of the components of the speech act of advice giving and responses. It consists of two main sections; the first reports the findings of the role play task, while the second reports the findings of the naturally occurring data.

\subsubsection{Role play task}

In order to make the task more realistic, the subjects were instructed to role play the situations in pairs using a cassette recorder to record their responses. Since it is an oral task, the role plays resulted in lengthy interactions in which there were always a lot of negotiations by both subject groups (Appendix 4).

In order to identify the components of the speech act of advice giving and advice responses, all subject performance on the role play task was analyzed and converted to moves. Then the frequency of each move (component) in all situations was calculated, converted to percentages and assigned a relative rank in relation to other components employed by each group (Tables 1 and 2).

Advice: In performing the speech act of advice giving both subject groups used numerous components, but generally speaking the American role plays were longer than the Egyptian ones. Table 1 shows all the components employed by Egyptians and Americans in the role play task.

Following are the most frequently employed components by each group (The parentheses indicate that the components inside are less frequent). 
Table 1: Components of advice giving in the role-play situations

\begin{tabular}{|c|c|c|c|c|c|c|}
\hline \multirow[b]{2}{*}{ Move } & \multicolumn{3}{|c|}{ Egyptians } & \multicolumn{3}{|c|}{ Americans } \\
\hline & $\begin{array}{l}\text { Frequency of } \\
\text { occurrences }\end{array}$ & $\begin{array}{l}\% \text { within } \\
\text { Egyptians }\end{array}$ & $\begin{array}{c}\text { Relative } \\
\text { rank }\end{array}$ & $\begin{array}{l}\text { Frequency of } \\
\text { occurrences }\end{array}$ & $\begin{array}{c}\% \text { within } \\
\text { Americans }\end{array}$ & $\begin{array}{c}\text { Relative } \\
\text { rank }\end{array}$ \\
\hline Directive & 219 & $34.9 \%$ & 1 & 168 & $27.6 \%$ & 2 \\
\hline Informative & 136 & $21.6 \%$ & 2 & 185 & $30.4 \%$ & 1 \\
\hline Preface & 45 & $7.2 \%$ & 3 & 47 & $7.7 \%$ & 4 \\
\hline Justification & 44 & $7.0 \%$ & 4 & 29 & $4.8 \%$ & 6 \\
\hline Inquiry & 36 & $5.7 \%$ & 5 & 53 & $8.7 \%$ & 3 \\
\hline Greeting & 22 & $3.5 \%$ & 6 & 26 & $4.3 \%$ & 7 \\
\hline Exclamation & 22 & $3.5 \%$ & 6 & 7 & $1.6 \%$ & 10 \\
\hline Assertive & 15 & $2.3 \%$ & 8 & 32 & $5.3 \%$ & 5 \\
\hline Offer & 12 & $1.9 \%$ & 9 & 17 & $2.8 \%$ & 8 \\
\hline Lack of intent to impede & 12 & $1.9 \%$ & 9 & 3 & $0.5 \%$ & 13 \\
\hline Proverb & 11 & $1.7 \%$ & 11 & 2 & $0.3 \%$ & 14 \\
\hline Compliment & 10 & $1.6 \%$ & 12 & 17 & $2.8 \%$ & 8 \\
\hline Statement of fact & 10 & $1.6 \%$ & 12 & 6 & $1.0 \%$ & 11 \\
\hline Religious expressions & 8 & $1.3 \%$ & 14 & 0 & $0.0 \%$ & 0 \\
\hline Warn & 7 & $1.1 \%$ & 15 & 4 & $0.7 \%$ & 12 \\
\hline Request & 7 & $1.1 \%$ & 15 & 0 & $0.0 \%$ & 0 \\
\hline Sarcastic remark & 5 & $0.8 \%$ & 17 & 2 & $0.3 \%$ & 14 \\
\hline Wish & 4 & $0.6 \%$ & 18 & 3 & $0.5 \%$ & 13 \\
\hline Personal opinion & 3 & $0.5 \%$ & 19 & 7 & $1.6 \%$ & 10 \\
\hline
\end{tabular}

Pre-advice moves: The components used by subjects before giving advice differed according to the situation as well as the relationship between interlocutors. However, the most commonly used strategies before advice include one or several of the following:

Egyptians: greeting - preface - exclamation - (compliment) - (proverb/religious expressions).

Americans: greeting - preface - exclamation - compliment.

In the pre-advice moves, the two subject groups showed partial similarity in terms of the components used. For example, both subject groups used greetings as an opening to the interaction especially in the situations in which the interlocutors were socially distant such as situations \#1 (Tired. Dep. Head), \#6 (Tired Student), and \#7 (Going to a far repair shop). Moreover, Americans were found to use greetings (4.3\%) slightly more frequently than Egyptians (3.5\%). However, in situations in which the interlocutors were socially close such as situations \# 2 (Nosy son), and \# 8 (Nosy parent), greetings were not employed by both groups.

Moreover, the two subject groups showed similarity in using a preface before the advice proper statement. A preface in the current study means a word, or a statement to attract attention or to indicate that the speaker has something to say. Interestingly enough, prefaces happened to be employed by both subject groups with rather similar percentages (Egyptians $=7.2 \%$ Americans $=7.7 \%$ ). Following are examples of such prefaces. The first example is from the Arabic data and the second from the English corpus. Phonetic transcription and translation follow each of the Arabic examples presented below.

Example (1) - Egyptian Arabic

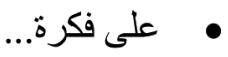

Eala fikra

By the way... 


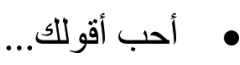

?ahib?a?u:1 lak

"I want to say..."

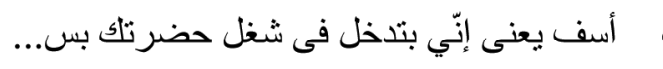

?x:sif jaeni inni batdaxal fi $\int u \measuredangle l$ hadritak bass...

Sorry to interfere, but ...

Example(2)-American English

I don't mean to be nosy but...

Oh, John I have to tell you something...

I don't want to interfere but ...

Exclamations were also a frequent component in the data collected from the two subject groups. An exclamation means a statement that shows astonishment and amazement. Both subject groups used exclamations directly before stating the advice to indicate that there was a problem and to prepare the hearer for the coming advice. One difference encountered, however, is that Egyptians used exclamations (3.5\%) more frequently than Americans did (1.6\%). Examples of such exclamations are:

Example (3)- Egyptian Arabic

$$
\text { با عم حد بيقى شابل الحاجات دي كلها وباخد منرو! }
$$

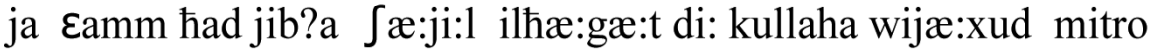

Carrying all these things and taking the metro!

$$
\text { بقى ما لقيتش إلا الاسبانى تدرسه! }
$$

Ba?a ma l?itfi illa il?asb:ni tidrisuh

Haven't you found anything but Spanish to study!

Example(4)-American English

Are you going to break your back just to save few dollars!

Oh that's terrible!

Another difference is that while compliments (utterances in which the speaker usually expresses his admiration of a person or something ) as a component were also frequent in the pre-advice sequence in the data collected from both groups, Americans employed them slightly more (2.8\%) than Egyptians (1.6\%) did. Examples of compliments are:

Example (5)- Egyptian Arabic

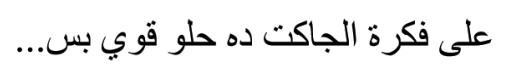

cla fikra il gæ:kit da hilu ?awi bass ...

By the way, this jacket looks nice, but...

Example (6) - American English

- You look nice in this jacket, but...

- This jacket is really cute.

One more important difference is that while proverbs were sometimes used before stating the advice in the Arabic corpus $(1.7 \%)$, they were almost rare in the American one $(0.3 \%)$. Moreover, it was noticed that while proverbs seemed 
to be used as a way of kidding in the American corpus, they were considered by Egyptians as popular sayings of wisdom meant to convince the other party of compliance. Examples of proverbs are:

Example (7)- Egyptian Arabic

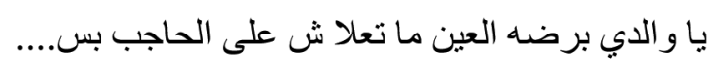

ja wæ:ldi: ba rduh ilci:n maticlæ: $\int$ cala ilhæ:gib bass ...

Literary "The eye will never become higher than the eyebrow"

$$
\text { • من تدخل فيما لا يعنيه سمع ما لا يرضيه. }
$$

man tadaxxal fi: ma la jacni:h sæmica ma la jurdi:h

Literary "He who interferes in others' affairs, will face what may displease him"

Example(8)-American English

- Oh, John burning the midnight oil in the library!

Another important, though less frequent, component was that of religious expressions. Interestingly enough, these expressions were unique to the Egyptian group (1.3\%). This finding may shed some light on the role of these expressions in communication among Egyptians, a phenomenon that needs investigation. Examples of religious expressions are:

Example (9)- Egyptian Arabic

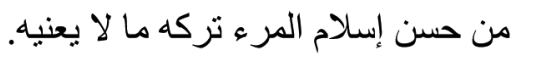

min husn islæ:m il-ma r? ta rkuh ma la jaci:h

A good Muslim minds his own business.

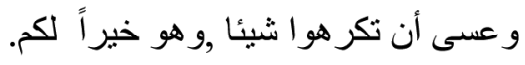

Wa casa ann takra hu: Jaj?an wa huwa xajran lakum

You might hate something and it is good for you.

Two reasons seem plausible for the use of such religious expressions in the advice sequence in Egyptian Arabic; first, they are considered less direct forms of advice giving. Secondly, they help to minimize advice resistance as they are convincing and difficult to refute.

Finally, it can be claimed that these strategies employed before advice might serve as face saving devices through which the speaker checks the feasibility of compliance and establishes grounds for the coming advice. This is not to say that all subjects of both groups employed such strategies before giving advice. Actually this was not the case because in some situations, especially when the interlocutors were socially close, they started with the head act directly.

Head act: This is the part that serves to perform the advice independently from other parts and it is the most important and the most difficult part to analyze. Actually there is no one fixed template to give advice in the two languages involved simply because this act could be formulated in various ways as is seen in this section. Following are the most frequent components used by each group to perform the head act. This is not to say that the head act should contain all these components. Actually, subjects used one or several of the following moves.

\section{Egyptians:}

Informative + directlindirect directive + inquiry + offer $+($ assertive $)+$ justification .

\section{Americans:}

Informative + directlindirect directive + inquiry + offer + assertive + justification.

Although both subject groups demonstrated a noticeable similarity along the variety of components they drew from, they demonstrated difference along the frequency of occurrence of each component. For example, both subject groups used informatives in the head act. An informative is usually a statement whose sole function is to provide information and to smooth transition to the act of advice giving. Informatives, however, were more frequently used by Americans 
(30.4\%) than by Egyptians (21.6\%). This may be due to the fact that in many exchanges Americans tended to use informatives only and leave the process of decision making to the advisee. Following are examples of informatives identified in the data.

Example (10)- Egyptian Arabic

$$
\text { • الكتاب ده موجود فى المكتبه اللي جنب الكلية بسعر ارخص شوية. }
$$

Ikkitæ:b da mawgu:d fi: ilmaktaba illi ganb ikullijja bisicr ?arxas Juwajja

They have this book at the store next to the college for a slightly lower price.

$$
\text { المترو هيبقى زحمه دلوقت. }
$$

Ilmitro hajib?a zahma dilwa?ti

The metro will be overcrowded now.

Example (11)- American English

- Norwegian is a very difficult language.

- Nosiness is not a good thing. People would be offended.

An informative is usually followed by a directive which is an utterance in which the advisor usually tries to get the advisee to do something. Directives, however, appeared in different forms according to the context of the situation. This was evident in the data analysis as directives varied from direct directives (unmitigated ones that usually contain verbs of necessity or obligation) to indirect directives (mitigated utterances in which there is no sense of obligation) such as suggestions and recommendations. This finding supports Hatch s (1992) study that "all languages have directives, but the variation in directive forms within a language must be sensitive to social constraints".

Despite the fact that directives were the most frequently used component by both subject groups in the advice sequence, Egyptians were found to employ them (34.9\%) relatively more than Americans (27.6\%) did. Examples of direct directives are:

Example (12)- Egyptian Arabic

$$
\text { • أنا قولت ميت مرة بلاش نكون فضولي مع الناس لازم ثوضع حد لفضولك ده. }
$$

?ana ?ult mi:t ma rra bælæ: Jtiku:n fudu:li maca innæ:s læ:zim tiwdae had lifudu:la k da

Ive told you many times before not to be nosy. It is necessary that you stop being nosy.

$$
\text { كفاية شغل كدة النهار دة أنت شكلك تعبان قوي وابقي كمل في يوم ثاني. }
$$

Kifæ:ja ?u?l kida innaharda ?inta ?aklak taebæ:n ?awi wi ib?a kammil fi: ju:m tæ:ni

That is enough for today, you look really tired. If there is anything left, you can resume it tomorrow.

Example(13)- American English

- Mind your own business.

- Go home and get some rest. You shouldn t be here all the time.

Note that the above utterances reflect a strong illocutionary force. They are stated directly without hedges. Compare with the following indirect directives:

Example (14)- Egyptian Arabic

$$
\text { •متهياً لي إن التاكسي أفضل لأن المترو هيبقى زحمة دلوقت. }
$$

Mithajja?li inn ittæksi ?a fda 1 li?ann ilmitro hajib?a zahma dilwa?ti

It seems to me that taking a cab will be better, the metro will be overcrowded now.

$$
\text { أنا شايفلك تعبت قوي النهاردة المفروض إنلك تستريح شوية ده جسمك ليه عليك حق. }
$$




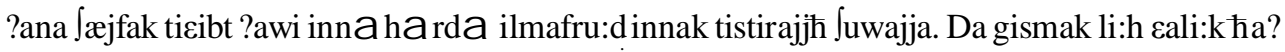

I see that you look really tired today. You should take some rest.

Example (15)- American English

- I think you need to go home and take a break.

- Hey wouldn $t$ it be easier to take a taxi with all that stuff?

Note that phrases like "I think...", "wouldn t it be easier..." carry a counseling tone that mitigates the force of the above directives.

Another component that both subject groups used is that of inquiry, which means a question whose function is to request a linguistic response. Such inquiries were slightly more frequently used by Americans ( $8.7 \%$ ) than by Egyptians $(5.7 \%)$

Example (16)- Egyptian Arabic

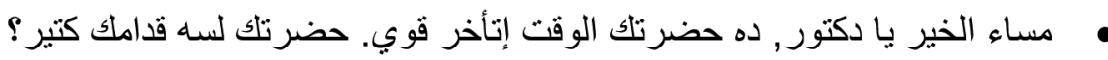

Mæ:ssa? Ilxji:r ja dukto:r da ћa drita k ilwa?t ?it?a xxa r ?awi ћa drita k lissa ?uddæ:mak

kiti:r

Good evening professor. It ,s too late. Will you stay here for much longer?

Example(17)- American English

- What s your interest in this particular language?

It is interesting, however, to note that both subject groups showed a general tendency to give advice masqueraded in the form of an offer or a suggestion most probably to reduce the face threat implied in the act of advising. This was particularly noticed in situation \# 1 (Tired. Department Head), and \# 5 (Carrying heavy things). Americans, however, were found to resort to this strategy slightly more often (2.8\%) than Egyptians did (1.9\%).

Example (18)- Egyptian Arabic

$$
\text { ياه با دكتور حضرتك شكلك مرهف قوي, في أب مساعده اقدر أقدمها ؟ }
$$

Jæ:h ja dukto:r. ћa drita k Jaklak murha q ?awi fi: ?ajj musæ $\varepsilon$ da ?a?da r ?a?addimha.

Oh professor, You look very tired can I help you?

Example(19)- American English

- I $m$ going the same way and I want to take a taxi. Would you join me?

Assertives were another component used by both groups, though with different frequencies of occurrence. Assertives in this study are statements in which the speaker usually coveys his belief, reports something that happened or asserts the existence of a particular situation. Americans, however, were found to employ assertives (5.3\%) more frequently than Egyptians did (2.3\%).

Example (20)-Egyptian Arabic

$$
\text { واضح إن حضرتك تعبان قوي }
$$

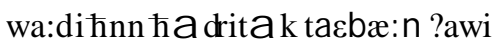

You look really tired.

$$
\text { أنا بصر احة شُفت أصحاب لي درسو أسباني لكن ما شُتغلوش بيه }
$$

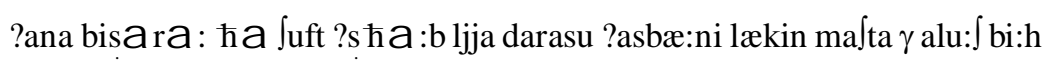

In fact some of my friends have studied Spanish but they didn't find a relevant job.

Example(21)-American English 
- I went there before and they really did a good job.

- I see you re working late this evening.

One more important component is that of justification or what Waring (2007) calls "accounts". These are utterances in which the advisor gives reasons for the advice. Justifications were employed by both subject groups either pre or post giving the advice. Of special interest here is the fact that Egyptians gave justification for their advice (7.0\%) more than Americans did (4.8\%). Following are examples of directives followed by justifications:

Example (22)- Egyptians Arabic

$$
\text { ما تشتريش الكتاب ده من هنا (directive) لأن المكتبة دي أسعار ها غالية (justification). }
$$

Matiftiri: Jikkitæ:b da min hina li?an ilmaktaba di ?asca rha $\gamma$ alja

Don't buy this book from this store; it's expensive.

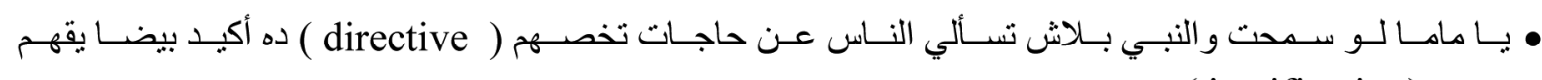
.( justification)

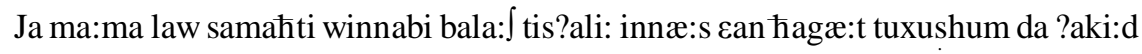

bijdaji?hum

Mum please don't ask people about their belongings. They must be annoyed this way.

Example (23)- American English

- Hey I think you should take a cab (directive). You've got a lot of stuff there and it could be a problem on the metro (justification).

- Listen son, you shouldn't be so nosy (directive). It s not polite. (justification).

Post advice moves: This part usually comes at the end of the exchange, i.e., after acceptance or refusal of the advice. The typical formulae to end the advice sequence in English were sentences like: "good bye" or "see you later", which usually indicate conversation closure. The same applies to the Arabic data in which the conversation ended with sentences like:

Example (24)- Egyptians Arabic

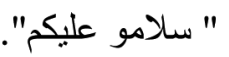

Sælæ:mu cali:kum

goodbye

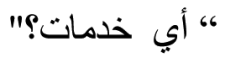

?aj xadama:t

Is there any thing I can do for you?

In some exchanges, especially when advice is refused, the advisor ended his advice with a statement to indicate that he does not intend to be intrusive. These statements were more frequent in the Arabic corpus (1.9\%) than in the American one $(0.5 \%)$.

Example (25)-Egyptians Arabic

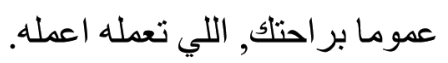

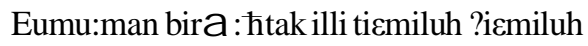

Any way, do whatever you want.

Example (26)- American English

? It was just a suggestion. 
Responses to advice: There was no particular pattern that could be identified in responding to advice. The responses varied from acceptance to refusal or even giving an indefinite reply. However, the most frequently used components were:

\section{Egyptians:}

Acceptance/refusal/(rejection)/(indefinite reply) + justification / explanation $+($ thanking $)+($ blame $) /($ reproach $)+$ (commissive).

\section{Americans:}

Acceptance/refusal/indefinite reply + justification/(explanation) + (blame) + thanking.

Table 2 shows all components used by Egyptians and Americans when responding to advice role play task

Table 2: Components of advice response in the role-play situations

\begin{tabular}{|c|c|c|c|c|c|c|}
\hline \multirow[b]{2}{*}{ Move } & \multicolumn{3}{|c|}{ Egyptians } & \multicolumn{3}{|c|}{ Americans } \\
\hline & $\begin{array}{l}\text { Frequency of } \\
\text { occurrences }\end{array}$ & $\begin{array}{l}\% \text { within } \\
\text { Egyptians }\end{array}$ & $\begin{array}{c}\text { Relative } \\
\text { rank }\end{array}$ & $\begin{array}{l}\text { Frequency of } \\
\text { occurrences }\end{array}$ & $\begin{array}{l}\% \text { within } \\
\text { Americans }\end{array}$ & $\begin{array}{c}\text { Relative } \\
\text { rank }\end{array}$ \\
\hline Refusal & 133 & $27.0 \%$ & 1 & 143 & $32.5 \%$ & 1 \\
\hline Justification & 100 & $20.3 \%$ & 2 & 93 & $21.1 \%$ & 2 \\
\hline Acceptance & 84 & $17.0 \%$ & 3 & 72 & $16.4 \%$ & 3 \\
\hline Explanation & 53 & $10.0 \%$ & 4 & 24 & $5.5 \%$ & 5 \\
\hline Commissive & 24 & $4.9 \%$ & 5 & 6 & $1.4 \%$ & 9 \\
\hline Indefinite reply & 15 & $3.0 \%$ & 6 & 23 & $5.2 \%$ & 6 \\
\hline Directive & 15 & $3.0 \%$ & 6 & 6 & $1.4 \%$ & 9 \\
\hline Reproach & 12 & $2.4 \%$ & 7 & 7 & $1.6 \%$ & 8 \\
\hline rejection & 9 & $1.8 \%$ & 8 & 1 & $0.2 \%$ & 12 \\
\hline Thank & 10 & $2.0 \%$ & 9 & 37 & $8.4 \%$ & 4 \\
\hline Blame & 10 & $2.0 \%$ & 9 & 8 & $1.8 \%$ & 7 \\
\hline Informative & 10 & $2.0 \%$ & 9 & 6 & $1.4 \%$ & 9 \\
\hline Self defense & 10 & $2.0 \%$ & 9 & 4 & $0.9 \%$ & 11 \\
\hline Lack of intent to impede & 5 & $1.0 \%$ & 10 & 5 & $1.1 \%$ & 10 \\
\hline Exclamation & 2 & $0.4 \%$ & 11 & 5 & $1.1 \%$ & 10 \\
\hline
\end{tabular}

In responding to advice, the study revealed that subjects had different options to choose from. The first and most frequent response, however, was refusal of advice. A refusal is a word or statement to indicate that the speaker will not comply and it was usually followed by a justification (accounts explaining why $\mathrm{H}$ prefers not to comply). Though refusals as a component were the most frequently employed response by both groups, they were employed by Americans (32.5\%) slightly more than by Egyptians (27.0\%). Interestingly enough justifications appeared in the Arabic corpus (20.3 $\%)$ with almost the same percentage as in the English one (21.1\%).

Example (27) - Egyptian Arabic

$$
\begin{aligned}
& \text { لامefusal) أصـل الإنجليزي أو الفرنسـاوي كتير فوي بيدرسهم لكن الأسـباني محدود ولذللك متهئ لـي هيكون } \\
& \text { أفضل(justification). } \\
& \text { la ?ạ̣l illingli:zi ?aw ilfaransæ:wi kiti:r ?awi bijdrishum lækin il?asbæni } \\
& \text { maћdu:d walizalik mithajja?li hæjkun ?afdal }
\end{aligned}
$$


No, everybody studies English and French but very few people study Spanish, so I think it would be better.

Example (28) - American English

No, (refusal) I hate taxi drivers and the metro is cheaper (justification).

It should be noted at this point that in refusing advice, the majority of American subjects reassured (or accepted) what the advisor stated saying "yes" then they gave their justification why they would not comply. This "yes, but ..." formula, or what Levinson (1983) calls "disagreement prefaced with token agreement", is usually used to save face of both $\mathrm{H}$ and $\mathrm{S}$ because it enables the advisee to refuse politely, while indicating that he/she is aware of what the advisor said but s/he has his/her reasons not to comply. So there will be no superiority of the speaker over the hearer. In other words, the advisee avoids performing an act which can be highly threatening to the advisor and also agrees with what the speaker said indicating that it is right. For example,

\section{Example (29)-American English}

A: Wouldn't it be better to study something that is a little easier and more useful like Spanish or French?

B: Yes, but (refusal) every body studies these languages and I like the idea of being unique (justification).

More interestingly, however, is that advice acceptance as a component happened to be employed by both groups with almost the same percentage (Egyptians $=17.0 \%$, Americans $=16.4 \%)$. Acceptance in this study means a word or a statement to indicate compliance or the intention to comply. It was sometimes followed by an explanation (a statement explaining the situation and indicating why the speaker complied). Though advice acceptance was sometimes followed by an explanation in Egyptian Arabic (10.0\%), Americans were found to give explanations (5.5\%) less frequently than Egyptians did.

Example (30)- Egyptian Arabic

$$
\text { • و الله عندك حق(explanation) (أنا محتاج أسأل كويس عن فرص عمله قبل ما أبدأ فى }
$$

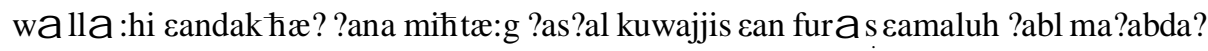

fi iddira : sa h

Yes, I think you're right. I need to ask about the job opportunities before I start studying.

Example(31)-American English

- Yes, (acceptance) I really need to sit down and talk to him about this (explanation).

Thanks for your concern (thanking).

A less frequent response, however, was that of giving an indefinite reply. In an indefinite reply the speaker usually produces utterances that indicate neither acceptance nor refusal. Though employed by both groups, indefinite replies were relatively more frequent in the American data (5.2\%) than in the Arabic corpus (3.0\%).

Example (32) Egyptian Arabic

$$
\text { الحياة عاوزة كدة. }
$$

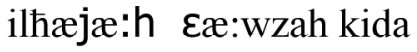

Actually, this is life.

Example(33)-American English

- I'm always a little bit tired with work (indefinite reply). Thanks for your concern. (thanking)

Although responses to advice were almost the same in basic content, differences could still be detected. For example, thanking or appreciation (a statement in which the speaker expresses his gratitude or appreciation) was more frequent in the English data (8.4\%) than in the Arabic corpus (2.0\%).e.g. 


\section{Example (34)- American English}

- I'll think about that (indefinite reply) but thanks for your concern (thanking).

- Oh actually they don't have this particular edition of the copy (justification). Thank you, I appreciate your concern (thanking).

Moreover, it was noticed that Egyptians sometimes used expressions of gratitude in a sarcastic tone, e.g.,

Example (35)- Egyptian Arabic

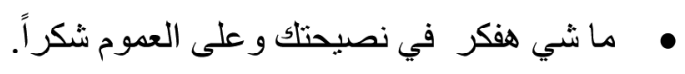

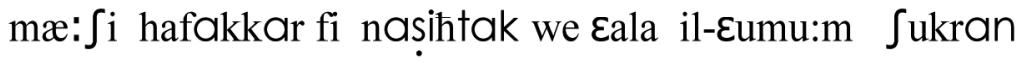

I'll think about your advice. Any way thanks for your concern.

Another difference is that in the case of acceptance, Egyptians sometimes committed themselves to complying (4.9\%) while most Americans did not (1.4\%).

Example (36)- Egyptian Arabic

$$
\text { • عندك حق إن شـاء الله أثنتريه بكره. }
$$

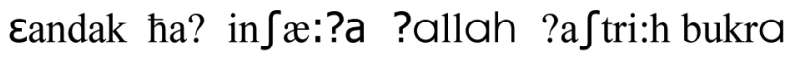

You 're right. I'll buy it tomorrow.

$$
\text { •الله ؟ أنا ها كنتش أعرف خلاص يبقي نستني. }
$$

walla:hi? ?ana makuntif ?Eraf xalas jb?a nistana

really? I didn't know that. I'll wait.

More important is the use of advice "rejection" or what might be called sarcastic acceptance: A statement in which the advisee indicates that he is fully aware of the advice. This component was more recurrent in the Arabic corpus (1.8\%) than in the English (0.2\%) one.

Example (37)- Egyptian Arabic

$$
\text { • }
$$

\section{?ah ma ana $\varepsilon æ: r i f a$ da kuwajjis}

yes , I really know this.

$$
\text { • بس أنت ما تقلقش أنا واخد بالى من الناحية دي كويس. }
$$

bass inta ma ti?la? $\int$ ana wæ:xid bæ:li min innahijh di: kuwajjis

Don't worry, I'm really aware of this.

The illocutionary force of these utterances is to tell the advisor not to show off superiority. In other words, they are meant to show that the advisee is aware of what the advisor is saying and does not need the advice. The use of this component on the part of Egyptian subjects could be explained in terms of what Triandis (1995) calls the different characteristics of high and low-context cultures. In a high-context culture such as Arabic, people tend to put more emphasis on the implicit rather than on the explicit. Thus, these utterances are usually left for the hearer to infer what the speaker intended to say. 
Another act, that of blaming (statements meant to make the advice giver sorry for giving the advice) happened to be employed by the two subject groups with almost the same percentage $($ Egyptians $=2.0 \%$, Americans $=1.8 \%)$.

Example (38)- Egyptian Arabic

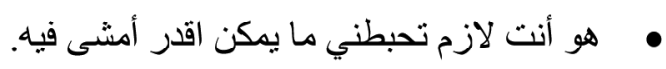

\section{huwwa ?inta læ:zim tihbitni ma jimkin ?a?adr ?am $\int i$ fi:h}

Why are you trying to disappoint me? May be I can manage.

Example(39)- American English

- It would be nice if you could be more supportive.

Closely related to the act of blaming is that of reproaching (Statements meant to offend the advice giver. They might imply some kind of insult). Reproach as a component was particularly employed in situation \#8 (nosy parents), which indicates that it is unacceptable and even inappropriate to give advice to a parent especially on something personal. Though employed by both groups, reproaching was more recurrent in the Arabic corpus (2.4\%) than in the English one (1.6\%).

Example (40)- Egyptian Arabic

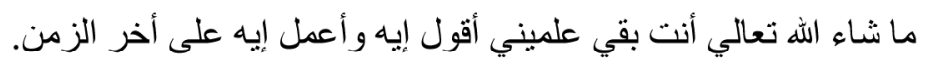

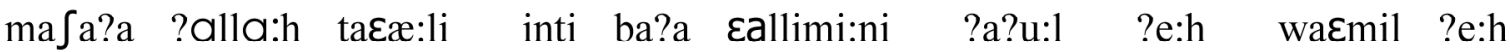

\section{Eala ?axir ?izzaman}

Oh great! So why don't you come and tell me what I should say and how I should behave.

Example(41)- American English

Listen son. I know our neighbor very well and I know what I can ask about. Don't tell me what to do.

These findings partially support Boxer's (1993) study that advice giving is not only a common act in parent-children interactions, but it is an act that may persist even after the children are adults and parents themselves. However, this study suggests that advice giving is more tolerated when directed from parents to children and not vice versa.

\subsubsection{Natural data}

Contrary to expectations, spontaneously collected data were not as long as the role plays in the two languages involved. Compared to the role play task, there were not many negotiations, the number of turns as well as the components were fewer. This may be due to memory loss or that data collectors did not record everything. However, it should be noted that naturally occurring advice giving in American English as L1 was the most difficult data to obtain. Consequently, the amount of collected data in English as L1 was very small as compared to natural data in Arabic. For a list of the moves identified in the naturally occurring advice giving in the two languages investigated as well as the frequency and percentage of each component in each language (Table 3).

Analysis of naturally occurring data shows that the most frequent componenrts were one or several of the following:

\section{Egyptians:}

$($ Preface $)+$ informative + directive + justification .

\section{Americans:}

Informative + justification + (directive) .

The general tendency we may observe here on the basis of the small corpus obtained is that Egyptians tended to use longer formulas than Americans did. The most frequently used component in Egyptian Arabic was that of directives $(23.8 \%)$. Other components identified were informative (19.0\%), justification $(19.0 \%)$, preface $(7.1 \%)$ and greetings $(9.5 \%)$. Moreover, it is interesting to note that most of the directives used by the Egyptian group were in the imperative 


\begin{tabular}{|c|c|c|c|c|c|c|}
\hline \multirow[b]{2}{*}{ Move } & \multicolumn{3}{|c|}{ Egyptian Arabic } & \multicolumn{3}{|c|}{ American English } \\
\hline & $\begin{array}{l}\text { Frequency of } \\
\text { occurrences }\end{array}$ & $\begin{array}{l}\% \text { within } \\
\text { Egyptians }\end{array}$ & $\begin{array}{c}\text { Relative } \\
\text { rank }\end{array}$ & $\begin{array}{l}\text { Frequency of } \\
\text { occurrences }\end{array}$ & $\begin{array}{l}\% \text { within } \\
\text { Americans }\end{array}$ & $\begin{array}{c}\text { Relative } \\
\text { rank }\end{array}$ \\
\hline Directive & 10 & $23.8 \%$ & 1 & 3 & $18.8 \%$ & 2 \\
\hline Informative & 8 & $19.0 \%$ & 2 & 5 & $31.3 \%$ & 1 \\
\hline Justification & 8 & $19.0 \%$ & 2 & 3 & $18.8 \%$ & 2 \\
\hline Greeting & 4 & $9.5 \%$ & 4 & 0 & $0.0 \%$ & 0 \\
\hline Preface & 3 & $7.1 \%$ & 5 & 1 & $6.3 \%$ & 5 \\
\hline Warn & 2 & $4.8 \%$ & 6 & 1 & $6.3 \%$ & 5 \\
\hline Exclamation & 2 & $4.8 \%$ & 6 & 1 & $6.3 \%$ & 5 \\
\hline Statement of fact & 1 & $2.4 \%$ & 8 & 0 & $6.3 \%$ & 5 \\
\hline Inquiry & 1 & $2.4 \%$ & 8 & 2 & $0.0 \%$ & 0 \\
\hline Recommend & 1 & $2.4 \%$ & 8 & 0 & $12.5 \%$ & 4 \\
\hline Sarcastic remark & 1 & $2.4 \%$ & 8 & 0 & $0.0 \%$ & 0 \\
\hline Forewarn & 1 & $2.4 \%$ & 8 & 0 & $0.0 \%$ & 0 \\
\hline
\end{tabular}

form. This, in turn, could be seen as an indication that advice giving is a socially accepted behavior in the Egyptian society more than in it is the American society. As for Americans, the most commonly employed components were informatives (31.3\%), justifications (18.8\%), directives (18.8\%), and inquiries (12.5\%).

These differences in the performance of the two groups are believed to be direct reflections of cultural differences. To be more specific, while using directives in Egyptian Arabic reflects the tendency of Egyptians to consider advice as an acceptable sign of helping others and maintaining solidarity, using informatives reflects importance that Americans assign to freedom of action, and independence, i.e., leaving it up to the hearer to decide on their future course of action. However, it should be admitted that the lack of an adequate amount of natural data in English hinders the generalizability of results.

When responding to advice, most Egyptians either accepted the advice (35.7\%) or gave an indefinite reply $(21.4 \%)$. Refusals, however, were not frequent in the Arabic natural data (13.3\%). Table 4 shows the components used by Egyptians and Americans when responding to advice in natural data.

Table 4: Components of advice response in naturally occurring data

\begin{tabular}{|c|c|c|c|c|c|c|}
\hline \multirow[b]{2}{*}{ Move } & \multicolumn{3}{|c|}{ Egyptians } & \multicolumn{3}{|c|}{ Americans } \\
\hline & $\begin{array}{l}\text { frequency of } \\
\text { occurrences }\end{array}$ & $\begin{array}{l}\% \text { within } \\
\text { Egyptians }\end{array}$ & $\begin{array}{c}\text { Relative } \\
\text { rank }\end{array}$ & $\begin{array}{l}\text { frequency of } \\
\text { occurrences }\end{array}$ & $\begin{array}{c}\% \text { within } \\
\text { Americans }\end{array}$ & $\begin{array}{c}\text { Relative } \\
\text { rank }\end{array}$ \\
\hline Greeting & 2 & $13.3 \%$ & 3 & 0 & $0.0 \%$ & 0 \\
\hline Preface & 0 & $0.0 \%$ & 0 & 1 & $6.6 \%$ & 5 \\
\hline Informative & 0 & $0.0 \%$ & 0 & 1 & $6.6 \%$ & 5 \\
\hline acceptance & 5 & $35.7 \%$ & 1 & 2 & $13.3 \%$ & 3 \\
\hline refusal & 2 & $13.3 \%$ & 3 & 5 & $33.3 \%$ & 1 \\
\hline justification & 2 & $13.3 \%$ & 3 & 3 & $20.0 \%$ & 2 \\
\hline indefinite reply & 3 & $21.4 \%$ & 2 & 1 & $6.6 \%$ & 5 \\
\hline thanking & 0 & $0.0 \%$ & 0 & 2 & $13.3 \%$ & 3 \\
\hline
\end{tabular}


It was also noticed that acceptance and indefinite reply were sometimes used in natural data just to close the conversation especially between acquaintances, i.e., socially distant interlocutors. Following is an example of an indefinite reply that appeared in the Arabic natural data

Example (48)- Egyptian Arabic

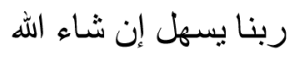

rabbina jisahhil in $\int æ: ? a$ alla:h

God willing: As for Americans, the most commonly employed components were refusal of advice (33.3\%) and justification (20.0\%). Other components were employed but less frequently. For example, acceptance and thanking were used with the same percentage (13.3\%). It should be stressed, however, that the lack of adequate amount of natural data in American English does not allow generalizability of results.

\section{Summary of the analysis of the components}

Analysis of the data obtained in the study revealed that very similar components were used by both groups when performing the speech act of advice giving and response in their mother tongues. Following is a summary of the most frequent components that were used by each group to perform the act of advice giving (The parentheses indicate that the components so enclosed are less frequent).

\section{Egyptians:}

$($ Greeting $)+($ preface $)+($ proverb/religious expressions $)+$ informative + directive $+($ inquiry $)+($ offer $)+$ justification.

\section{Americans:}

$($ Greeting $)+($ preface $)+($ exclamation $)+$ informative + directive + (inquiry $)+($ offer $)+($ assertive $)+$ justification.

Though similarities are much more striking than differences in the components employed by the two groups to perform the act of advice giving, differences do exist in the order and frequency of each component. For example, offering as a component, though identified in the two languages, was more frequent in the English data than in the Arabic corpus. Moreover, proverbs and religious expressions appeared in the Arabic corpus only, which suggests that religion could be a fundamental motivating force in many aspects of the Egyptian culture. However, it should be noted that both subject groups were similar in using informatives, directives and justifications (accounts) as three major components in advice giving.

In terms of the number of components employed to perform this act, however, some differences were identified dependent on the data collection method. For example, while role plays resulted in lengthy interactions and considerable negotiations, natural data resulted in shorter interactions in which there were no such negotiations. Moreover, it should be noted that the number of the components used to perform the act of advice giving ranged from one component in some cases (mostly either an informative or a directive), to five or more different components in different situations. Another important finding is that although directives constitute one major component in the act of advice giving, sometimes several components constituted the act of advising without necessarily having a directive. For example, the speech act of advice giving sometimes consisted of: preface + informative + inquiry + offer. In such a case, the addressee had to infer the illocutionary force implied in the act performed. This was true in the two languages involved.

When responding to advice, on the other hand, several components seemed to be available (e.g., acceptance, refusal, and rejection). These components, however, varied according to the situation, the relationship between interlocutors, and the level of directness of the advice. Following are the most frequently employed components when responding to advice.

\section{Egyptians:}

acceptance/refusal/rejection +justification / explanation + (thank) + blame + commissive.

\section{Americans:}

acceptance/refusal +justification / explanation +(blame) + thank.

Though components employed by both groups in response to advice seem to be relatively similar, some differences were identified. For example, the component of "advice rejection" appeared in the Arabic corpus only. Moreover, thanking as a component was more frequent in the American corpus $(8.4 \%)$ than in the Arabic one (2.0\%). However, it 
should be noted that whether advice is addressed directly or indirectly, both groups were in agreement that justifications (accounts) represent one major component in the act of advice giving and response in the two languages involved. This finding strongly agrees with Waring (2007) in that justifications or "accounts" are a major component in the advice giving sequence especially in post advice sequence, as they show that the advice giver displays "a keen interest in the recipient's understanding, not just acceptance of the advice". Equally important, however, the researcher believes, is giving accounts when refusing a piece of advice because it helps to avoid any misunderstandings and saves the face of both parties.

To sum up, it should be noted that not all of the above-mentioned components of the act of advice giving and response were present in every encounter. Actually, "conversation is not a structural product in the same way a sentence is - it is rather the outcome of the interaction of two or more independent, goal directed individuals with often divergent interests" (Levinson, 1983). That is to why the identified components actually differed according to the social and linguistic context. Accordingly, these components are treated as a template rather than a complete description of the act of advice giving, and this template is subject to disorder, addition, and omission in actual advice giving encounters. These findings lend support to those of DeCapua and Huber (1993), and DeCapua and Dunham (1995) that native speakers of American English rarely use specific forms in giving advice. Instead, they found that in American English, native speakers use a variety of different discourse strategies, and that very often advice is embedded in larger narrative contexts.

Interestingly enough, however, and unlike other performative verbs such as "promise", "thank", and "complain", the verb "advise" was never used performatively in the English data. No one used the formula "I advise you..."; all American subjects used non-performative utterances to perform this act. However, its counterpart in Arabic namely, " was used three times in the Arabic corpus. This could be an indication that while the verb "advise" could be used performatively in Arabic, it might sound odd if used performatively in English. This may be because the speech act of "advice giving" may imply some kind of showing off superiority which is against the values of American society that stresses independence and individualism. However, using this verb performatively in the Egyptian society shows how Egyptians probably see this act from a different angle. In other words, it reflects that advice giving is tolerated and even welcomed in the Egyptian society to establish and maintain some kind of rapport as showing care and interest in each others' well being.

These findings do not only lend support to Wierzbicka's (1985) claim that advice is formulated tentatively in English and that the verb advise "is seldom used performatively in ordinary speech: the phrase I advise you sounds very stiff and formal", but they reveal that such a claim applies to advice giving in Arabic as well. The findings of the study also supports earlier research findings that while speech acts themselves are universal, the socio-pragmatic rules or norms governing the performance of these acts vary among cultures and languages (Cohen and Olshtain, 1993; Eisenstein and Bodman, 1993; Matsumura, 2001; Felix-Brasdefer, 2004).

Moreover, it was observed that numerous strategies were used by both groups to soften the face threat implied either in the act of advice giving or in advice response. Following is a list of the most salient strategies employed by each group to reduce the face threat implied in the act of advice giving and response. The most frequently employed strategies by the American group were:

- Using words and phrases like: I believe, I think, I'm wondering, kind of, may be, possibly, perhaps, try, to be honest.

- Making suggestions and even offers instead of giving advice.

- Giving accounts/justifications for the advice.

- Providing accounts/justifications why not to comply.

Similar strategies were used by Egyptians to reduce face threat when giving and responding to advice in Egyptian Arabic. Following are the most commonly employed ones.

- Using words and phrases like

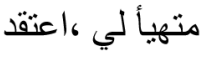

- Using interrogatives and consultative devices like 
- Giving lengthy explanations and accounts.

- Using proverbs, religious expressions and even some verses from the Holy Qur'an to show politeness and sincerity.

Overall, the two subject groups can be claimed to have used remarkably similar strategies to soften either advice or response. Egyptians, however, were unique in using religious expressions and proverbs which show sincerity and serve as a face saving device.

Although it was not the focus of our study, the relationship between politeness and directness is extremely important. The results of the study support previous research (Brown and Levinson, 1987; El-Shafey, 1990) that there is a positive correlation between the degree of politeness and that of indirectness. Additionally it was found that Egyptians used other means than indirectness to express politeness. They used proverbs, religious expressions and some Qur'anic verses. The function of these strategies is to reinforce the advice, reduce the amount of face threat and to save face of both parties. These results are consistent with Gabr (1990) and El-Shazly (1993) who identified similar strategies when performing the acts of requesting and thanking respectively.

Finally it can be concluded that the findings of the study supports the stereotypical description of Americans as being more individualistic, and independent (Ting-Toomey, 1999; Yasuhiko 2001, 2001a, and 2001b) than Egyptians. Besides, they also support the stereotypical description of Arabs in general and Egyptians in particular as being collectivist and group oriented (Hofstede, 1991; Triandis, 1995; and Ting-Toomey, 1999).

\section{References}

Boxer, D. (1993). Social distance and speech behavior: the case of indirect complaints. Journal of Pragmatics, 19, 103125.

Boxer, D. (1996). Ethnographic interviewing as a research tool in speech act analysis: the case of complaints. In S.M. Gass and J. Neu, (Eds.), Speech Acts Across Cultures (pp.217-239). Berlin: Mouton de Gruyter.

Brown, J. (2005). The effect of a study abroad on acquiring pragmatics. M.A. Thesis. Center for Language Studies Brigham Young University. http:// contentdm. lib.byu.edu/ ETD/image/etd942.pdf. Retrieved on 20/2/2008

Brown, P. and Levinson, S.C. (1987). Politeness: Some Universals in language Usage. Cambridge: Cambridge University Press.

Burton, D.(1980). Dialogue and Discourse: A sociolinguistic approach to modern drama dialogue and naturally occurring conversation. London: Routledge and Kegan Paul

Byon, A. (2006). Apologizing in Korean: Cross-cultural Analysis in Classroom Settings. Korean Studies, 29,137-166.

Cohen, A. and Olshtain, E. (1993). The production of speech acts by EFL learners. TESOL Quarterly, 27(1), 33-56.

Coulmas, F. (1981). Poison to your soul, Thanks and apologies contrastively viewed. in F. Coulmas (Ed.), Conversational routine: explorations in standardized and prepatterned speech (pp. 69-91). The Hague: Mouton Publishers.

Crystal, D. (1985). A Dictionary of Linguistics and Phonetics.(2nd ed.). Oxford: Blackwell.

Davies, E. (1987). A contrastive approach to the analysis of politeness formulas. Applied Linguistics , 8, 75-88.

DeCapua, A. and Dunham, J. F. (1993). Strategies in the discourse of advice. Journal of Pragmatics, 20(4), 519-530.

DeCapua, A. and Huber, L. (1995). 'If I were you ...' Advice in American English. Multilingua, 14(2), 117-132.

Eisenstein, M. and Bodman, J. (1993). Expressing gratitude in English. In G. Kasper and S. Blum-Kulka (Eds.), Interlanguage Pragmatics (64-81). New York: Oxford University Press.

El-Shafey, F. (1990). Politeness strategies in spoken british english and spoken egyptian arabic: a contrastive study. Unpublished Ph. D. Thesis. Cairo University.

El-Shazly, A. (1993). Requesting strategies in american english, egyptian arabic and english as spoken by egyptian second language learners. Unpublished M.A. Thesis. The American University in Cairo.

Felix-Brasdefer, C. (2004). Interlanguage refusals: Linguistic politeness and length of residence in the target community. Language Learning, 54(4), 587-653.

Ferguson, C. (1981). The structure and use of politeness formulas. In F. Coulmas.(Ed.), Conversational Routine: Explorations in Standardized and Prepatterned Speech (pp.21-35). The Hague: Mouton Publishers.

Fujimori, J. and Houck, N. (2004). Practical criteria for teaching speech acts. The Language Teacher, 28(5), 3-8. 
Gabr, A. (1991). Thanking in American English and Egyptian Arabic: A cross-linguistic cross-cultural study. Unpublished M. A. Thesis. The American University in Cairo.

Hatch, E. (1992). Discourse and Language Education. Cambridge: Cambridge University Press.

Hinkel, E. (1997). Appropriateness of advice: DCT and multiple choice data. Applied Linguistics, 18, 1-25.

Hofstede, G. (1991). Cultures and organizations: software of the mind. London; New York: Mc-Graw-Hill.

Levinson, S. (1983). Pragmatics. Cambridge: Cambridge University Press.

Matsumura, S. (2001). Learning the rules for offering advice. A quantitative approach to second language socialization. Language Learning. 51, 635-679.

Nelson, G.L., El-Bakary, W. and Al-Batal, M. (1996). Egyptian and American complaints: focus on second language learners. In S.M. Gass and J. Neu (Eds.), Speech Acts Across Cultures (pp. 109-128). New York: Mouton de Gruyter.

Nydell, M.K. (1996). Understanding Arabs: A Guide for Westerners. Yarmouth, Maine: Intercultural Press, Inc.

Park, M. (2002). Differences in the advice giving Behavior Between Korean EFL Learners and English Native Speakers. SNU Working Papers in English Language and Linguistics, 1, 62-91.

Searle, J.R. (1969). Speech Acts: An Essay in the Philosophy of language. Cambridge: Cambridge University Press.

Salah El-Din, Y. (2000). Complaints in Egyptian Arabic and American English: A Cross-Linguistic Cross-Cultural study. (Doctoral Dissertation). Cairo University, Egypt.

Ting-Toomey, S. (1999). Communicating across cultures. New York: The Guildford Press.

Triandis, H. (1995). Individualism and Collectivism. Oxford: West View Press.

Tsui, A. (1994). English Conversation. Oxford: Oxford University Press.

Wardhaugh, R. (1985). How Conversation Works. Cambridge, MA: Basil Blackwell.

Waring, H. (2007). The multi-functionality of accounts in advice giving. Journal of Sociolinguistics, 11(3), $367-391$.

Wierzbicka, A. (1985). Different cultures, different languages, different speech acts. Journal of Pragmatics, 9, $145-178$.

Wierzbicka, A. (1991). Cross-cultural pragmatics: The semantics of human interaction. Berlin: Mouton de Gruyter.

Yasuhiko, M. (2001). "Want" in advice giving context- a corpus based analysis. www. Fukushima-nct.ac.jp/ eng/ miyazawa/ paper2 html/ want.Html/untitledhtml. Retrieved on 25/8/2003.

Yasuhiko, M. (2001a).The mechanism of indirectness \& politeness. www. Fukushimanct.ac.jp/ eng/miyazawa/ paper.2html/want.2html/want2.html. Retrieved on 25/8/2003.

Yasuhiko, M. (2001b). The grammaticalizatian of desideratives to semi-modals. www.fukushima-nct-ac.jp/ eng /miyazawa/ paper2.html/ want3 html/ want $3 \mathrm{html}$. Retrieved on 25/8/2003. 
Appendix 1A

\section{مواقف تمثيلية}

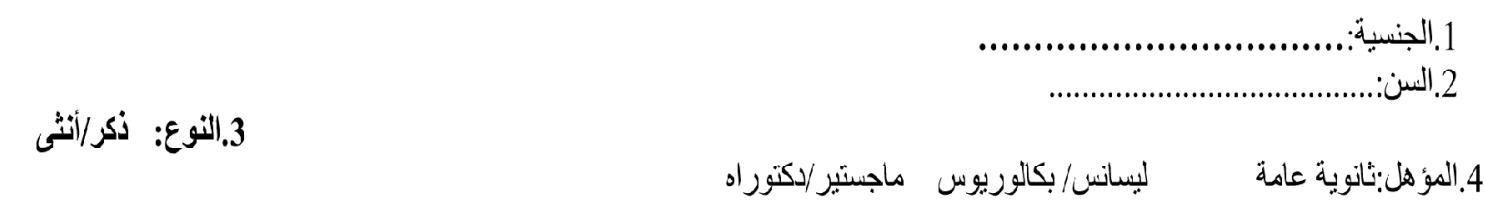

تخيل نفسك في العواقق ألأتيه هنتقول إيه ؟أو ماتثقلش حاجه؟ وليه فى حالة لو ها قولتش حاجه؟ 1-أنت طالب جاهعي ثُفت رئيسن القسم بيثتنل في الهكبة لغاية وقت هتأخر وباين عليه تعبان قوى هنتول له إيه؟أو ماتقولش حاجه؟ وليه

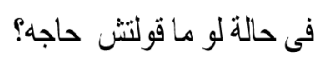

2- ابنك اللي عمره عشرين سنه فضولي فوبي ودايماً ينحشر في اللي مالكش فيه. وامبار ح وانتو مروحين فابلتو واحد من الجيران شايل علبه ملفوفة بشكل حلو جداً ابنكأك سأله إيه اللي في العلبة دي؟ وجاييها لمين؟ وأنت شايف إن الفضول الزيادة دة حاجه مش كويسه هتقول لابنكا إيه ؟أو ماتقولش حاجه؟ وليه فى حالة لو ما قو لتش حاجه؟

3-و احد من أعز أصحابك بيفكر في دراسة اللغة الأسبانية. وأنت عارف أنها لغة صعبة قوى واستخدامها محدو و وانه في لغات تانية أسطل وأحسن كثير زى الانجليزيه أو الفرنسية. هتقول إيه؛ أو ماتقولش حاجه! وليه فى حالة لو ما قولثش حاجه؛

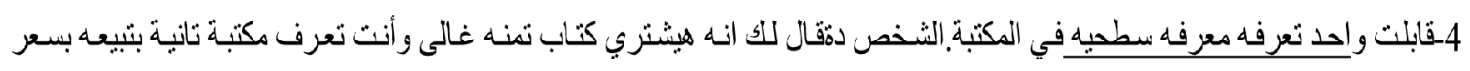
أرخص. هثقول إيه ؟أو ماتقولش حاجه؟ وليه فى حالة لو ما قوتن حاجه؟

5ـ واحد من أعز أصحابك رايح مشو از بعيد و شايل حاجات كثيرة وتقيله ومع كذة قال أنه هير كب المثرو وأنت شايف إن التاكسي أفضل. هنقو له إيه ؟أو ماتقولش حاجه؟ وليه في حالة لو ما قولتش حاجه؟

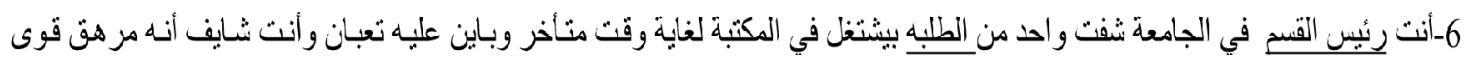
ومحتاج بستريح هنقول إيه ؟أو ماتقو لش حاجه؟ وليه فى حالة لو ما قولت حاجه؟ 
Appendix 1A (Cont.)

7- واحد تعزفه هعرفه سطحية رايح بصلح عربيته عند ورشها بعيدة وأنت تعرف ورشة تانية اقرب بكتير جربتها فبل كده الثخص دة

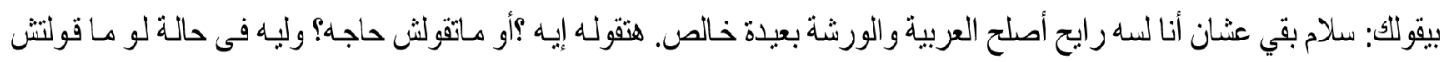
حاجه؟

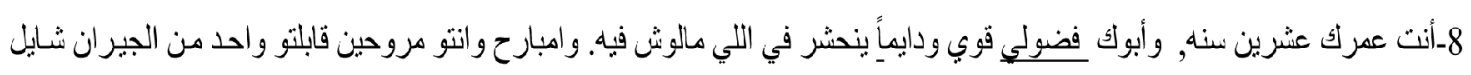
علبه ملفوفة بشكل حلو قوى والاك سأله إيه اللي في العلبة دي؟ وجيبها لهين؟ وأنت شايف إن الفضول الزيادة دة حاجه هش كوبسه هثتول لأبوك إيه ؟أو ماتثق لش حاجه؟ ولبه في حالة لو ما قولتش حاجه؟

9ـ أنت رئيس قسم فى الجامعة وواحد من الطلبة تخين جداً قابلت الطالب دهى في الكفيتريا في وقت الغداءو ولاحظت أنه بياكل سكريات

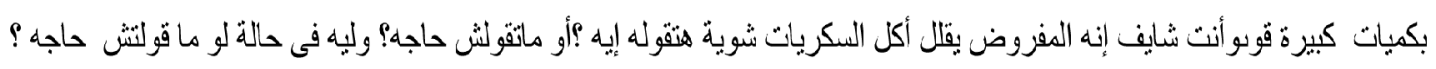
10- مديرك في النغل شخص محبوب جدا وقريب منك وأنت في محل لبيح الملابس قابلت المدير ولقيته هينترى جاكت غالنقوى وأنت سمعت إن الاوكازيون هيبدأ بكره هنتقوله إيه ؟أو ماتقولش حاجه؟ وليه في حالة لو ما قولتش حاجه؟

11- قابلت واحد من أعز أصحابك بيشتغل في مكتبه لغاية وقت متأخر وأنت شُايف إنها تعبان قوى ومحتاج يستريح. هثقوله إيه بأو ماتقو لش حاجه؟ وليه فى حالة لو ما قولتش حاجه؟

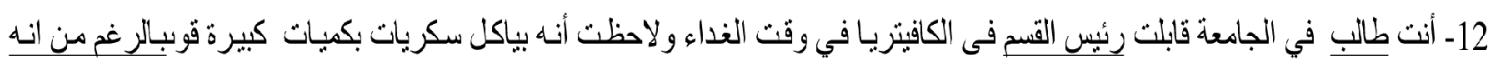

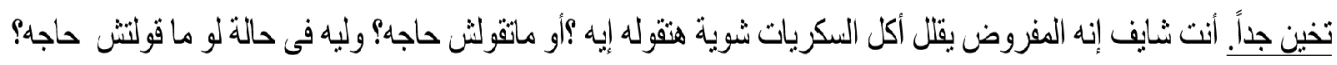
13ـ أنت مدير محبوب جذا. قابلت سكرنبرك في محل لييع الملابس و لقيته هيشترى جاكت غالى جدا. أنت سمت إن الاوكازيون هيبداً بكره هنتوله إيه ?أو ماتقولش حاجه? وليه فى حالة لو ما قولثش حاجه؟ 


\section{Appendix 1A (Cont.)}

14- و احد تعرفه معرفه سطحيه جذا بيتحق التزقية ومع ذلك المدير رفي واحد ثانى بدلا منه عشان كده أنت شابف انه شخص سلبي وشخصيته

$$
\text { ضعيفة و المفروض انه يقدم شنكوى قابلت الثخص ده يدور بينكم الحديث التالي : }
$$

أنت : هتعمل إيه في موضوع الترقية بتاعتلك ده المفروض انك تستحق الترقية من فتره ؟

هو :يا للحه ما هو المدير تخطاني في الثرقية وأنا ففيث في ايدى حاجه اعملها.

هتقو له إيه؟ أو ماتقو لث حاجه? وليه فى حالة لو ما قو لتش حاجه؟

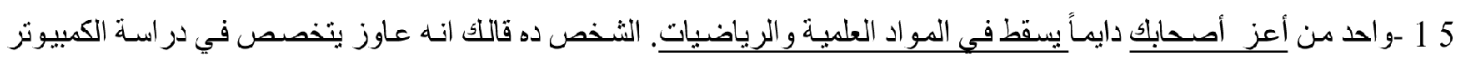

وتكنولوجيا المعلومات.و أنت شايف انه من الأفضل له انه يختار تخصص أسهل زى در اسـة الأدب مثنالألن دراسـة الكمبيوتر صعبه عليه

هثقو له إيه ؟أو ماتقولث حاجه؟ وليه فى حالة لو ما قولتث حاجه؟

16- و احد تعرفه معرفه سطحيه دايماً هدو مه مكر مثه خالص و الثخص ده هيتقدم لوظيفة جديدة عشان كده أنت شايف انه لازم يحسن مظهره

$$
\text { شوية قابلته ودار بينكم الحديث الثالي: }
$$

هو: ده أنا عندي بكره مقابله شخصبه عشان الوظبفة الجدبدة دعو اتك معانا بقي.

هتقوله إيه ؟أو ماتقولش حاجه؟ وليه في حالة لو ما قولتش حاجه؟ 
Appendix 1B

\section{مو قفت تمثيلية}

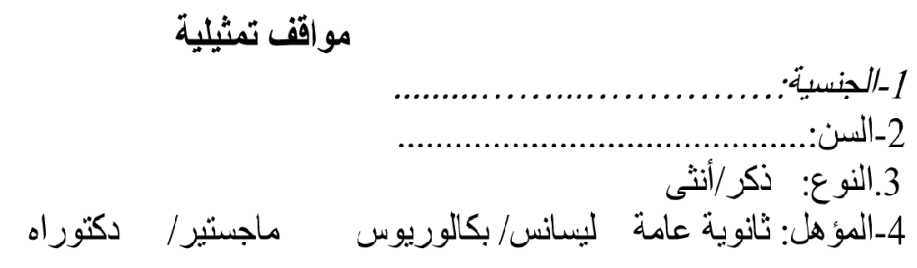

تخيل نفسك في المواقف ألأتيه هتقول إيه ؟أو ما هتقولش حاجة؟بليه؟

1-أنت أستاذ في الجادعة كنت بتشتغل في الدكنبه لغاية وقت متأخر حاسس انك تعبان قوى قابلت واحد من الطلبة في

المكتبة اسمع هيقب لكك إيه ورد عليه.

2- أنت شاب فضولي جداو عمرك عشرين سنه، امبارح وأنت وو الدك مروحين قابلتتر واحد من الجيران شـايل علبه

ملفو فة بثكل حلو قوى أنت سألته إيه اللي في العلبة دي؟ وجايبها لمين؟ اسمع أبوك هيقولك إيه ورد عليه

3ـ قلت لأعز أصحابك انك بتفكر في دراسة اللغة الأسبانية, اسمع صاحبك هيقولك إيه ورد عليه.

4ـ قابلت واحد تعر فه معر فه سطحيه في المكتبة وقلت له انك فررت تشتري كتاب ثمنه غالى شوية لأنك بندور عليه من فترة وأخيرا لقيته اسمع الثخص دة هيقو للك إيه ورد عليه.

5- أنت واعز أصحابك مروحين. أنت شـايل حاجات كتبرة وتقبله ور ايح مشوار بحيد ومـع ذلك قلت لصـاحبك انك هتركب المنرو اسمع صاحبك هيقولك إيه ورد عليه.

6ـ أنت طالب في الجامعة كنت بتثتخل في المكتبة لغاية وقت متأخرقوي في حاسس انك تعبان قابلت رئبس القسم اسمع هيقولك إيهورد عليه.

7- أنت عايز تصلح عر بينك فلت لواحد معرفه انك رايح نصلحها عند ورشها بعيدة لأنك مـا تعرفش غير هـا اسمع 


\section{Appendix 1B (Cont.)}

8- أنت و ابنك اللي عمره عشرين سنه مروحين, وقابلتو واحد من الجيران شـيل علبه ملفوفة بشكل حلو قوى أنت سلمت علبه وسألته إيه اللي في العلبة دي؟ وجايبها لمين؟ اسمع ابنك هيقولك إيه ورد عليه.

$$
\text { 9-أنت طالب تخين جداً وبتحب تاكل سكريات كثبر, قابلت رئبس القسم في الكافيتريـا و إنت بتاكل كميه كبيرة من }
$$

10ـ أنت ددير محبوب جدا وقريب من الموظفين بنو علك. قابلت واحد من الموظفين وأنت في محل ليبع الملابس وقلت له انك بتفكر تتشري جاكت غالت شوية اسمع هيقولك إيه ورد عليه.

11-أنت موظف في شركه كبيرة كنت بتتنغل في مكتبك لغاية وقت متأخرقوي في حاسس انك تعبان قابلت واحد من أعز أصحابك اسمع هيقولك إيه ورد عليه.

12- أنت رئيس قسم تخين جداً وبتحب تاكل سكريات كتير, قابلت واحد من الطلبة في الكافيتريا وإنت بتاكل كميه كبيزة من الحلويات اسمع هيقولك إيه ورد عليه.

13- أنت في محل لبيع الملابس و هتتنترى جاكت غالى جدا.قابلت المدير بتاعلك وهو شخص محبوب جدا اسمع هيقو للك إيه ورد عليه.

14- أنت تستحق الترقية ومع ذلك الدير رقي واحد تانى بدلا منك قابلت واحد تعرفه معرفه سطحيه جدا سألكك عن الترقية فقلت له انه مفيش في ايدك حاجه تعملها. اسمع هيقولك إيه ورد عليه.

5 - أنت دايماً نسقط في المو اد العلمية والرياضيات. ومع ذلك قلت لو احد من أعز أصحابك انكأك عاوز تتخصص في در اسة الكبيوتر وتكنولوجيا المعلومات. 
Appendix 1B (Cont.)

16- أنت مابتهتمش بمظهرك خالص و هدومك دايماً مكر مشه،و هنتقدم لوظيفة جديدة وقابلت واحد من معارفكك وقلت له: ده أنا عندي بكره مقابله شخصبه عشان الوظيفة الجديدة دعو اتكك معانا بقي. اسمع هيقو للك إيه ورد عليه. 
Appendix 2A

\section{Role Play}

Nationality:

Gender:.

Age:.

Education: High School

University Education M.A. / PH.D.

Look at the following situations and respond to them as you would if you found yourself in the same/similar ones. If you wouldn't say any thing, please tell us why you wouldn't say anything. Your participation is very much appreciated.

1. You are an undergraduate student and you see your department head working in the library very late in the evening. Your department head looks very tired. You think that he should take some rest. How would you advise him/her? If not, why not?

2. You are the father of a twenty - year- old son who is very nosy. While you and your son were going home, you met one of your neighbors carrying a beautifully wrapped box. After greeting your neighbor, your son asked him what was inside that box and for whom he brought it. You believe that being nosy is a very bad habit. How would you advise him? If not, why not?

3. One of your close friends is considering studying the Norwegian language. You've heard that Norwegian is a really difficult language and with limited use. So you think that it is better for your friend to study any other language such as English or French because they are a lot easier and of more practical use. How would you advise him/her? If not, why not?

4. You see one of your distant acquaintances in a bookstore. He is considering buying an expensive book. However, you know another store that sells it at a lower price. How would you advise him/her? If not, why not?

5. Your life long friend is going home, carrying a lot of heavy things. You know that your friend's house is so far, however he mentioned something about going home by the metro. You think that it is better for him to take a taxi rather than trying to save money. How would you advise him/her? If not, why not?

6. You are the department head. You see one of your undergraduate students working in the library very late in the evening and looking really tired. You think that he needs to take some rest. How would you advise him/her? If not, why not?

7. One of your distant acquaintances is thinking of taking his car to a repair shop downtown because he does not know a nearer one. However, you know of a closer shop on the corner where you have taken your car. How would you advise him/her? If not, why not?

8. You are a twenty-year- old son. Your father is a very nosy person. While you and your father were going home, you met one of your neighbors carrying a beautifully wrapped box. After greeting your neighbor, your father asked him what was inside that box and for whom he brought it. You believe that being nosy is a very bad habit. How would you advise your father? If not, why not?

9. You are the department head. One of your undergraduate students is very fat. You meet him in the cafeteria and you notice that he eats a lot of fat food and sweets. You think that he should avoid eating sweets. How would you advise him/her? If not, why not?

10. You are in a department store where you meet your manager, who is very friendly. The manager is going to buy an expensive jacket. However you know that the sale starts tomorrow. How would you advise him/her? If not, why not?

11. You see one of your close friends working at his office very late in the evening and looking really tired. You think that he should take some rest. How would you advise him/her? If not, why not?

12. You are an undergraduate student. Your department head is very fat. You meet him in the cafeteria and you notice that he eats a lot of fat food and sweets. You think that he should avoid eating sweets. How would you advise him/her? If not, why not? 


\section{Appendix 2A (Cont.)}

13. You are a very friendly manager. You and one of your employees are in a department store; your employee is considering buying an expensive jacket. You know that the sale season starts tomorrow. How would you advise him? If not, why not?

14. One of your distant acquaintances deserves to be promoted this year. Unfortunately, instead of promoting him, the manager promoted someone else who does not deserve the promotion. You ask your acquaintance if he was going to file a grievance to get the promotion, he says that he can do nothing about it. You think that he has a very passive and weak character. How would you advise him/her? If not, why not?

15. One of your close friends always fails in mathematics and scientific courses. However, he told you that he wants to study computer science. You think that its better for him to study an easier branch like commerce or literature because he is not such an intelligent person to study computer science. How would you advise him/ her? If not, why not?

16. One of your distant acquaintances does not really care about his appearance. You noticed that his clothes always need ironing. You know that he is going to apply for a new job, so you think that he should take care of his appearance. How would you advise him/ her? If not, why not?

\section{Thanks for your co-operation. If you have any comments, please write them down.}

\section{Comments:}




\section{Role Play}

Appendix 2B

\section{Nationality :}

Gender:.

Age:.

Education: High School

M.A/PH.D.

Look at the following situations and respond to them as you would if you found yourself in the same/similar ones. Your participation is very much appreciated.

1. You are the department head. One of your undergraduate students saw you working in the library very late in the evening and looking tired. Listen to what your student would say, then produce a suitable reply.

2. You are a twenty -year-old son and you are a very nosy person. While you and your father were going home, you met one of your neighbors carrying a beautifully wrapped box. After greeting your neighbor, you asked him what was inside that box and for whom brought it. Listen to what your father would say, then produce a suitable reply.

3. You told one of your close friends that you are considering studying the Norwegian language. Listen to what your friend would say, then produce a suitable reply.

4. You meet one of your distant acquaintances in a bookstore. You are considering buying an expensive book. Listen to what he would say then produce a suitable reply.

5. You are going home and carrying a lot of heavy things. Your house is so far. You tell your life long friend that you will go home by the metro. Listen to what your friend would say, then produce a suitable reply.

6. You are an undergraduate student. Your department head saw you working in the library very late in the evening and looking tired. Listen to what your department head would say, then produce a suitable reply.

7. You told one of your distant acquaintances that you are thinking of taking your car to a repair shop downtown, because you do not know a nearer one. Listen to what s/he would say, then produce a suitable reply.

8. You are a father of a twenty-year- old son and you are a very nosy person. While you and your son were going home, you met one of your neighbors carrying a beautifully wrapped box. After greeting your neighbor, you asked him what was inside that box and for whom brought it. Listen to what your son would say, then produce a suitable reply.

9. You are an undergraduate student and you are very fat. As you are eating a lot of fat food and sweets in the cafeteria, your department head sees you. Listen to what he would say, then produce a suitable reply.

10. You are a very friendly manager. You meet one of your employees at a department store. You are considering buying an expensive jacket. Listen to what your employee would say, then produce a suitable reply.

11. You are working in your office very late in the evening and looking tired. One of your close friends sees you. Listen to what s/he would say, then produce a suitable reply.

12. You are the department head. Actually you are a very fat person, however you cannot help eating sweets. As you are eating a lot of fat food and sweets in the cafeteria, one of your undergraduate students sees you. Listen to what s/he would say, then produce a suitable reply.

13. Your manager is a very friendly person. You see him at a department store. You are considering buying an expensive jacket. Listen to what s/he would say, then produce a suitable reply.

14. You deserve a promotion this year. The manager, however, has promoted some one else who does not deserve the promotion. You meet one of your distant acquaintances who asks you about the promotion and you tell him that there is nothing you can do about it. Listen to what s/he would say, then produce a suitable reply.

15. You always fail in mathematics and scientific courses. However, you decided to study computer science. Listen to what your close friend would say, then produce a suitable reply. 


\section{Appendix 2B (Cont.)}

16. You tell one of your distant acquaintances that you are going to apply for a new job. Listen to what he would say, then produce a suitable reply.

Thanks for your co-operation. If you have any comments, please write them down.

\section{Comments:}


Appendix 3A

\section{بطاقة جمع وتسجيل المعلومات}

هذه بطاقة لجمع وتسجيل أساليب النصح والإرشاد باللغة العربية, من فضلك:

ه لا تجعل الأشخاص المحيطين بك يشعرون أن ما ياور بينهم يتم تسجيله

• حاول أن تكتب الحوار كما يحدث أمامك بالضبط.

•حاول أن تعتمد على فراستك وسياق الموقف لتحديد كل من أعمار المتحدثين وكذلك العلاقة بينهم.

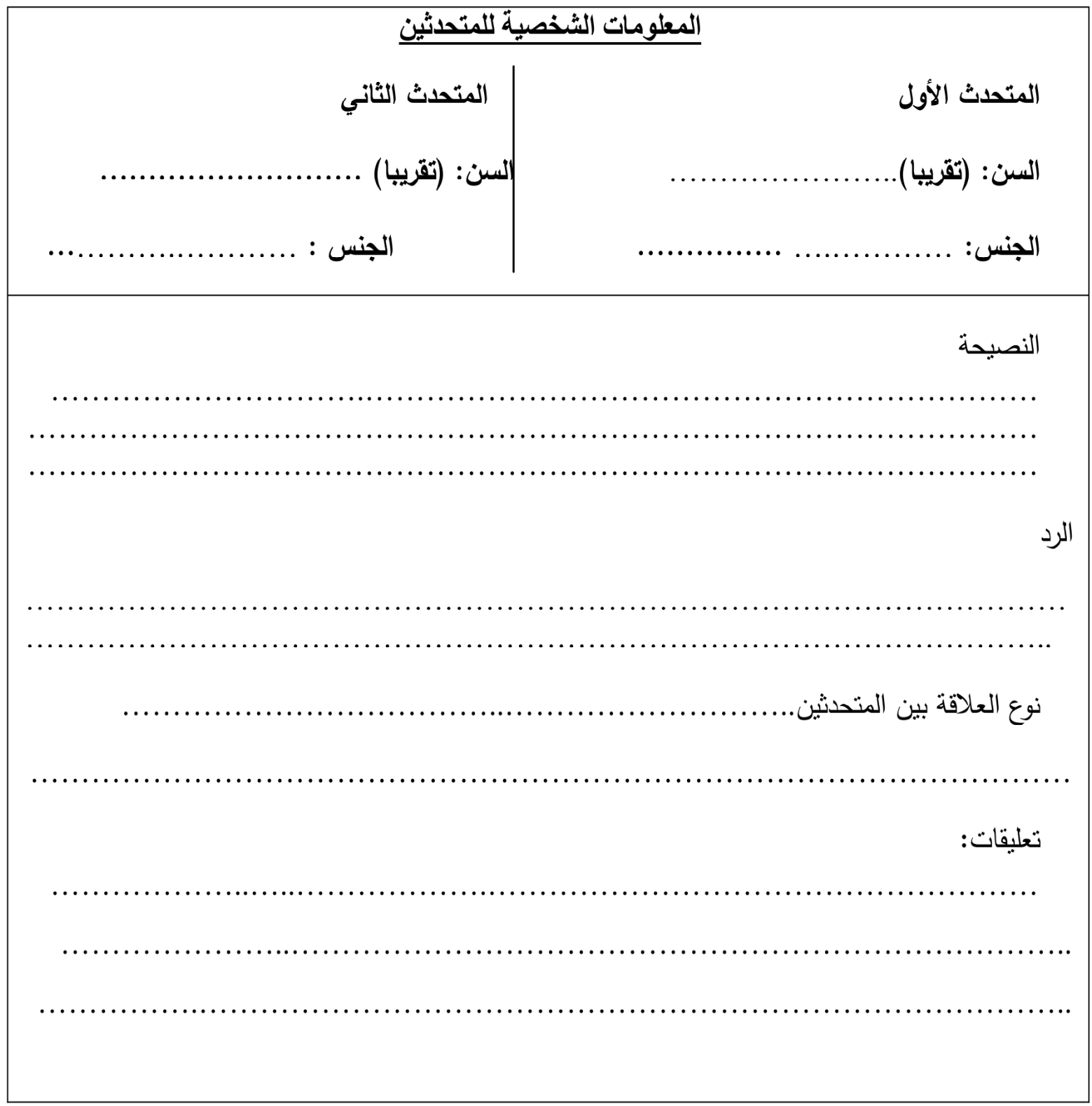




\section{Appendix 3B}

\section{Observation Sheet}

This is an observation sheet designed to collect naturally occurring pieces of advice and responses. Please,

- Do not let the subjects discover that their conversation is being recorded.

- Try to write the conversation exactly as it occurred.

- Use your discretion and the context to determine the age of the speakers under investigation as well as the relationship between them( formal, informal, strangers acquaintance...etc).

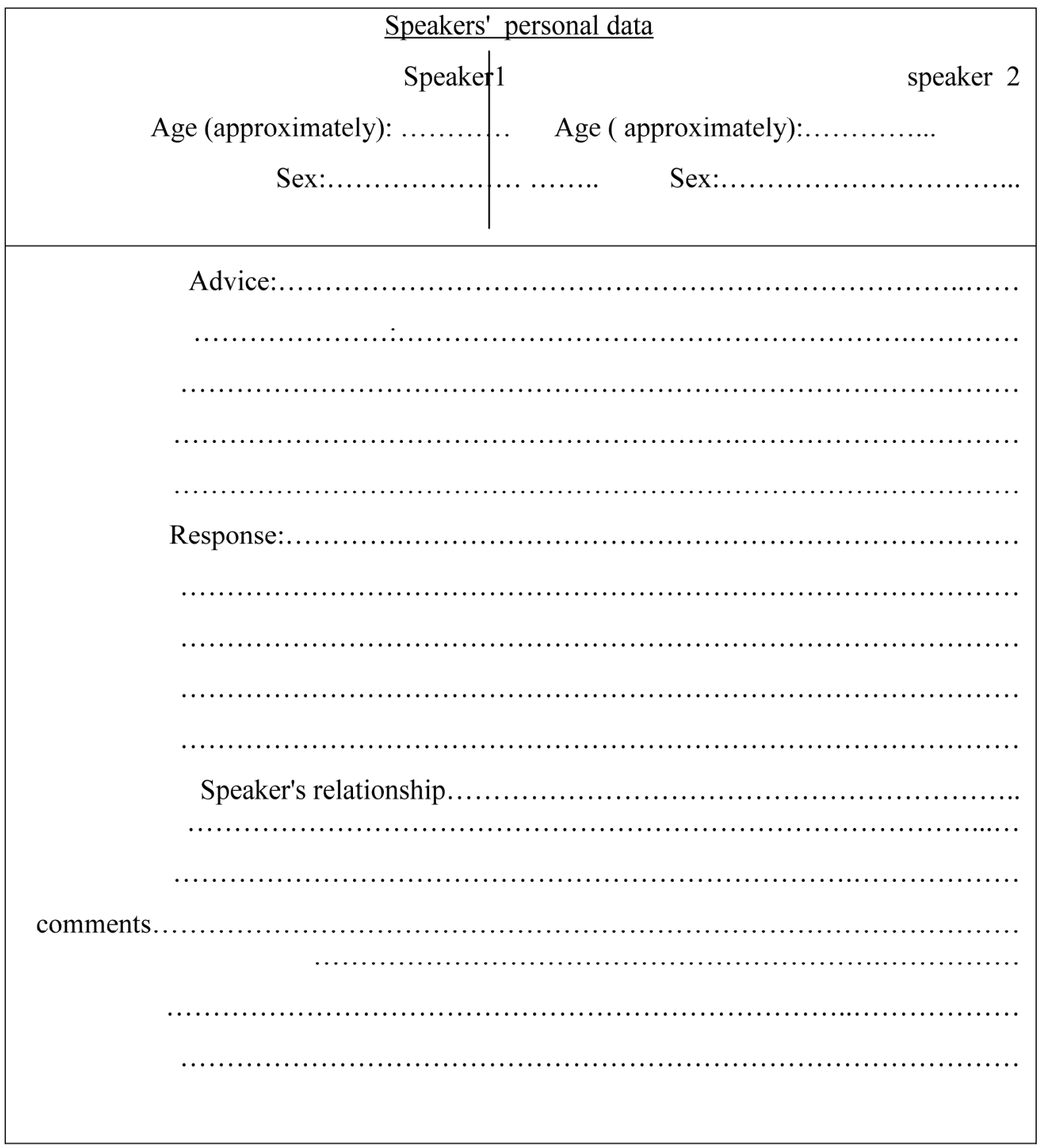


Appendix 4

\section{Examples of Egyptian and American role plays}

The following interactions in Arabic and English illustrate the components mentioned in the above sections. Each two of these interactions are taken from the same situation; one example is from the Arabic data and the other from the English corpus. The components are labelled between parentheses.

\section{Example (42)- Egyptian Arabic}

(Situation 13, Appendices 1a, 1b)

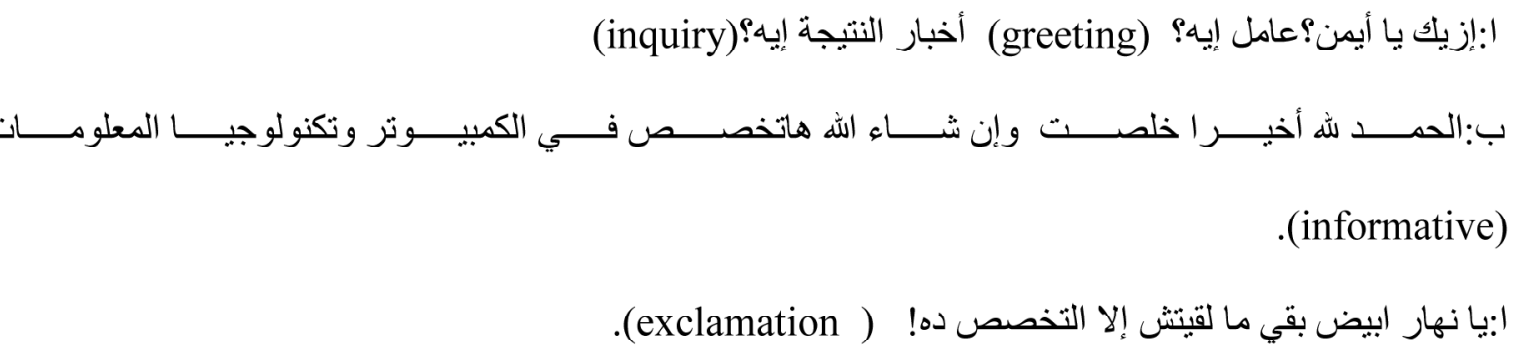
ب:ليه يا بنى ده لغة العصر ! (exclamation) (ب) أ:يا عم أول ما شطح نطح زى ما بيقولو (proverb) ـ إهدا شوية كدة وحاول تدخل كلية على قدلك(directive) أنت ناسي أنك كنت بتسقط فى الرياضدة والكيميا (justification). خش يا عم آداب و لاتجاره كده و لا حاجه (directive). ب: لا (refusal) بس أنا فكرت وشايف إن الكمبيوتر مستقبله أفضل (justification). وبعدبن عادي يعني لو يأسنا من كل حاجة علثان فشلنا فيها ييقي نيأس من الحياة كلها (informative).

\section{Phonetic transcription of example (42)}

a. ?izajjak ja ?ayman عæ:mil ?e:h ?xba:r innati:ga ?e:h

b. ilhamdu lillæ:h ?axi:ran xallașt winn Jæ:? alla:h hatxassas fi ilkumbjo:tar wetiknulo:g ja ilmaclu:mat

a. ja nha:r ?abjad ba?a mala?it $\int i$ illa ittaxassus da 


\section{Appendix 4 (Cont.)}

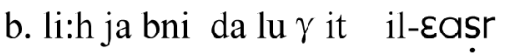

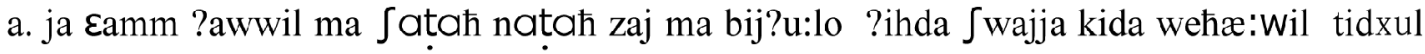
ku:llijja Eala ?addak ?inta næ:si innak kunt btis?at fi irrija:da wilkimja xu $\int$ ja Eam æ:dæ:b walla tiga:ra kida walla ћæ:ga

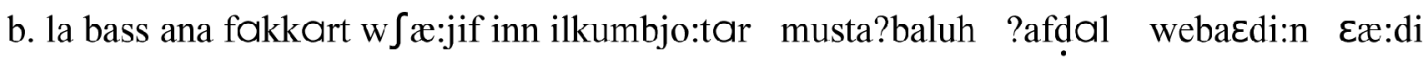

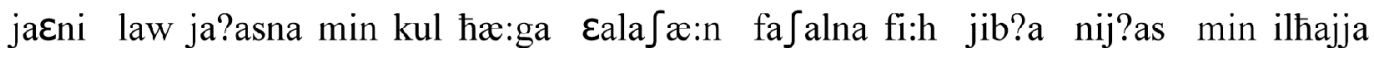
kullaha

\section{Translation of example (42)}

a. How are you Ayman? What about you exam results?

b. Thanks God, I've finally finished and I'm going to study computer science.

a. what! haven't you thought of something else?

b. Why? It's the language of the age.

a. "As soon as he takes a course of action, he goes too far"! Think for a while and try to study something that is appropriate for you. Do you remember how many times you failed in mathematics and chemistry. Why don't you study literature or commerce or something like that?

b. No, I've thought enough and I think computer science is better. If we lose hope because we've failed in one thing before, we'll lose hope of the whole life.

Note the use of several moves (greetings, inquiry, exclamation), before moving to the head act. Moreover, the head act consists of a proverb, a directive, and a justification for the directive followed by another directive, which shows that directives are a main component in the act of advice giving in Egyptian Arabic.

\section{Example (43)- American English}

(Situation 13, Appendices 2a,2b)

a: Hey Jim, nice to see you here. How are you doing? (greeting) 
Appendix 4 (Cont.)

b: Fine (reply) how is every thing going? (greeting)

a: Every thing is going well (greeting).

b: I heard that you're interested in computer science.( assertive)

a: Yea, I think I'm going to study it. There are a lot of work opportunities in that field (explanation).

b: Right, but ... you know, computer science is very complicated (informative). I think that you might have problems in it as you had trouble in math and science (warn). So I think it would be a better idea if you study something easier like literature or commerce (directive).

a: Yea, but (mitigated refusal) computer science is important. I could actually get a job with it. I want to study something that is really useful (justification).

b: I was just suggesting (explanation).

a: Well, thanks (thanking).

Note that while this interaction consisted of nine turns, its counterpart in Arabic consisted of six turns. Note also that the head act consists of a variety of acts (an informative, a warning and a directive) as opposed to the Arabic data in which directives were prevalent.

\section{Example (44)- Egyptian Arabic}

(Situation 1, Appendices 1a,1b)

ا: هساء الخير يا دكتور ( greeting)، على فكرة حضر تلك شكالك تعبان قوي(assertive) يا ترب في أب هساعدة أقدر

$$
\text { (offer) أقدمها (2) ( }
$$

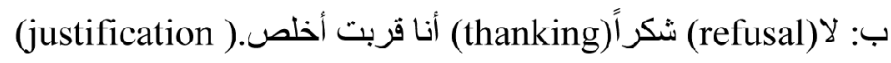

\section{Phonetic transcription of example (44)}

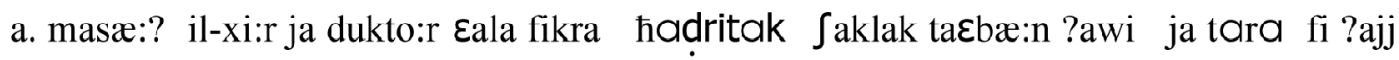
musaeda ?a?dar ?a?addimha 


\section{Appendix 4 (Cont.)}

b. la Sukran ?ana ?arrabt axallas.

\section{Translation of example (44)}

a. Good evening doctor, you look really tired. Can I help you ?

b. No, thanks. I'm almost done.

Note that the act of advice giving is packaged as an offer probably to minimize resistance to advice.

\section{Example (45)- American English}

(Situation 1, Appendices 2a, 2b)

a. Excuse me sir, I don't want to be nosy (preface) but you look really tired. (assertive). I just wanted to make sure that you are all right (inquiry).

b. 'Thank you for coming by and noticing. (thanking) I' $\mathrm{m}$ ok. (reply) I just have a presentation tomorrow.(explanation).

a. Can 1 get you coffee or something? (offer)

b. No, no (refusal) thank you ( thanking)

a. Oh, good luck with your presentation.(wish).

b. Thank you (thanking). Have a nice day (wish). See you in class ( closure).

a. See you in class.(closure)

Note that while the Arabic role play consisted of two turns, the English one consisted of seven turns. A plausible explanation for the production of relatively short role plays on the part of the Egyptian group might be that conducting such role plays in the Egyptian society is not as common as it is in the American one. Consequently, this task might have sounded odd to Egyptians.

\section{Example (46)- Egyptian Arabic}

(Situation 2, Appendices 1a, 1b) 
Appendix 4 (Cont.)

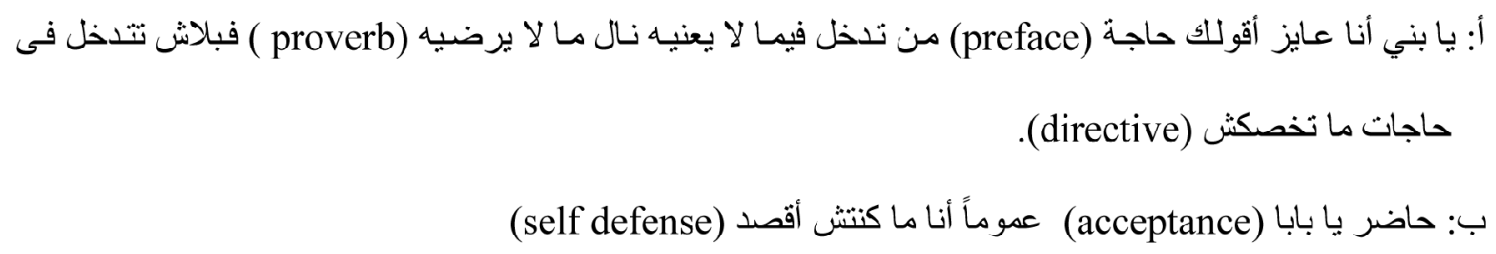

\section{Phonetic transcription of example (46)}

a. ja bni ?ana عæ:jiz ?a?u:l lak ћæ:ga man tadaxxal fi ma la jeni:h næ:la ma la jurdi:h fa balæ: $\int$ titdaxxal fi hægæ:t matxussak $\int$

b. ha:dr ja ba:ba ?ana makunti ? ?a?sud

\section{Translation of example (46)}

a. Listen son I want to tell you that "he who interferes in others' affairs, will face what may displease him". You shouldn't be so nosy.

b. Ok dad, anyway I didn't mean to be nosy.

Note that the proverb in the previous example is meant to convince the advisee and to minimize resistance to advice. Moreover, the fact that the son accepted the advice without negotiations might reflect his keen interest in showing respect and deference to his parent.

\section{Example (47)- English}

(Situation 2, Appendices 2a, 2b)

A: Son you have been a little bit nosy when you asked what was in the box.( accusation)

That might not be tactful.(informative) You just need to respect people's

privacy.(directive)

B: I was just asking what was inside the box.(justification) I didn't think I had done anything wrong (refusal). 


\section{Appendix 5}

\section{Operational definitions of components identified in the performance of the two groups when giving and responding to advice}

Acceptance: A statement that indicates agreement or compliance with the initiated advice.

Assertive: A statement in which the speaker usually coveys his belief about something or asserts the existence of a particular situation.

Blame: A statement meant to make the advice giver regret giving the advice.

Commissive: A statement in which the advisee commits himself to comply.

Compliment: An utterance in which the speaker usually expresses his admiration of a person or something.

Directive: An utterances in which the advisor tries to get the advisee to do something whether directly or indirectly.

Exclamation: A sentence meant to express surprise or astonishment of a particular situation.

Explanation: An utteranec explaining the situation and indicating why the speaker complied.

Indefinite reply: An utterance that indicate neither acceptance nor refusal of the advice.

Greeting : A word or phrase to welcome someone, e.g. "hello", "good morning" ...etc.

Informative: A statement whose sole function is to provide information and to smooth transition to the act of advice giving.

Inquiry: A question asked in order to get information.

Justification: Giving reasons for not doing a certain act.

Lack of intent to impede : A statement meant to indicate that the speaker dose not intend to impede one's freedom of action

Offer: A statement to indicate the willingness to give something to someone.

Preface: A statements to indicate that the speaker has something to say. 


\section{Appendix 5 (Cont.)}

Personal opinion: A statement to express what one thinks about a particular subject or a situation.

Proverb: A short well-known phrase or sentence, which contains advice about life.

Recommendation: A statement meant to tell $\mathrm{H}$ that something is good or useful.

Refusal: A statement to indicate the $\mathrm{H}$ will not comply.

Rejection: A statement to indicate the $\mathrm{H}$ will not accept the advice and that he is fully aware of it.

Religious expression: A phrase or sentence related to religion, most probably used to show sincerity in giving the advice.

Reproach: Statements meant to offend the advice giver.

Request: To ask for something.

Sarcastic remark (joke): A statement in which S says something funny to make people laugh.

Self defense: A statement in which the speaker tries to protect himself from being criticized.

Statement of fact: A statement to report facts.

Thanking: A statements to express gratitude.

Warning: A statement indicating that a certain course of action is not in the hearer's best interest.

Wish: A statement in which the speaker indicates that $\mathrm{s} / \mathrm{he}$ wants something to happen 